\title{
Seed fate and seedling dynamics after masting in two African rain forest trees
}

\author{
Julian M. Norghauer ${ }^{1}$ and David M. Newbery \\ Institute of Plant Sciences, University of Bern, 21 Altenbergrain, 3013, Bern, Switzerland
}

\begin{abstract}
How the effects of biotic factors are moderated by abiotic factors, and their consequences for species interactions, is generally understudied in ecology. A key abiotic feature of forests is regular canopy disturbances that create temporary patches, or "gaps," of above-average light availability. Co-occurring in lowland primary forest of Korup National Park (Cameroon), Microberlinia bisulcata and Tetraberlinia bifoliolata are locally dominant, ectomycorrhizal trees whose seeds share predator guilds in masting years. Here, we experimentally tested the impact of small mammal predators upon seedling abundance, growth, and survivorship. In 2007, we added a fixed density of seeds of each species to exclosures at 48 gap-understory locations across 82.5 ha within a large Microberlinia grove, and at 15 locations outside it.

For both species, small mammals removed more seeds in gaps than in understory, whereas this was reversed for seeds killed by invertebrates. Nonetheless, Microberlinia lost twice as many seeds to small mammals, and more to invertebrates in exclosures, than Tetraberlinia, which was more prone to a pathogenic white fungus. After six weeks, both species had greater seedling establishment in gaps than understory, and in exclosures outside compared to exclosures inside the grove. In the subsequent two-year period, seedling growth and survivorship peaked in exclosures in gaps, but Microberlinia had more seedlings' stems clipped by animals than Tetraberlinia, and more than twice the percentage of leaf area damaged. Whereas Microberlinia seedling performance in gaps was inferior to Tetraberlinia inside the grove, outside it Microberlinia had reduced leaf damage, grew taller, and had many more leaves than Tetraberlinia.

No evidence was found for "apparent mutualism" in the understory as seedling establishment of both species increased away from $(>25 \mathrm{~m})$ large stems of either species, pointing to "apparent competition" instead. In gaps, Microberlinia seedling establishment was lower near Tetraberlinia than conspecific adults because of context-dependent small mammal satiation. Stage-matrix analysis suggested that protecting Microberlinia from small mammals could increase its population growth rate by 0.06 . In the light of prior research we conclude that small mammals and canopy gaps play an important role in promoting species coexistence in this forest, and that their strong interaction contributes to Microberlinia's currently very poor regeneration.
\end{abstract}

Key words: apparent competition; canopy gaps; Korup National Park; Microberlinia bisulcata; pathogens; plant-animal interactions; seedling recruitment; seed predation; small mammal predators; species coexistence; Tetraberlinia bifoliolata; tropical lowland forest.

\section{INTRODUCTION}

Many tree species produce very large numbers of offspring, many of which die soon after dispersal (Ridley 1930, Janzen 1971, Shugart 1984, Lieberman 1996, Richards 1996, Turner 2001). This loss of seedlings can markedly change the local spatial distributions of many tree species (Mellanby 1968, Janzen 1970, Augspurger 1983, Clark and Clark 1984, Howe et al. 1985, Packer and Clay 2000, Tomita et al. 2002). Once a seed has landed on the ground its survival depends on a large number of factors acting simultaneously, many of

Manuscript received 24 November 2010; revised 16 March 2011; accepted 22 March 2011. Corresponding Editor: R. T. Corlett.

${ }^{1}$ E-mail: julian.norghauer@ips.unibe.ch which are linked to the seed's immediate location (Howe and Smallwood 1982, Chambers and MacMahon 1994, Crawley and Long 1995, Hart 1995, Curran and Webb 2000, Hulme and Kollmann 2005). An important factor, which has been shown to act selectively upon species reproductive behavior and morphology, is seed predation (Janzen 1969, 1971, 1974, Hulme and Benkman 2002, Kelly and Sork 2002). Seed predation may, therefore, have significant consequences for the population growth rates that determine local tree abundance (Hulme 1998, Maron and Crone 2006; e.g., Silman et al. 2003).

In the context of the fallen-seed-to-sapling dynamics, seed predation is one of four main factors, the others being seed limitation, microsite availability and quality (for germination, establishment, and growth), and 
subsequent herbivory on seedlings. Predation and herbivory can depend on the relative abundances of trees, such that where conspecific adults are clustered susceptibility to enemies is greatest, this lending a survival advantage to being locally rare (Ridley 1930, Janzen 1970, Connell 1971). The impact on species abundance is expected to be greater for species that are more strongly limited by seed than microsite availability (Harper 1977, Crawley 1989, Poulsen et al. 2007). Although the four factors are clearly not mutually exclusive, more often than not they have been studied separately; very rarely for instance has seed germination and seedling establishment been followed after controlling for seed predation and microsite features (Schupp and Fuentes 1995, Hulme 1998, Hulme and Kollmann 2005, Clark et al. 2007; but see Howe and Brown 2001, Paine and Beck 2007, Bricker et al. 2010). A further little-studied dimension is the extent to which seeds are affected by pathogens (Watt 1919, Dalling et al. 1998).

The longevity of trees is generally high, and this makes evaluation of the effects of seed and seedling predation at the population and community levels difficult (Lieberman 1996, Richards 1996, Turner 2001). Numerous studies have indeed reported on the magnitude of predation on seeds and seedling establishment (reviews by Harper 1977, Hammond and Brown 1998, Hulme 1998, Turner 2001, Hulme and Benkman 2002, Moles et al. 2003, Carson et al. 2008). They suggest that species identity, seed size, seed density and/ or distance to parents, and habitat (or microsite) can all influence the magnitude of post-dispersal seed predation and seedling recruitment. The relative importance of each variable and the consequences for longer-term dynamics, are less clear, however (Sork 1987, Clark et al. 2007, Paine and Beck 2007). These uncertainties have arisen because guilds of predators were not always distinguished, and sampling was often not sufficiently representative of plant populations and predators (Schupp 1992, Hulme 1998, Curran and Webb 2000, Hulme and Kollmann 2005).

Even so, and surprisingly, few studies in tropical forests have examined seed predation at scales larger than the individual adult tree; that is, at the population level, by involving spatial replication. In Panama, Schupp (1992) did this by tethering seeds of a subcanopy tree species (Faramea occidentalis) at 10 locations within 25 ha. In a Peruvian forest, Losos (1995) transplanted seeds of two palms (Iriartea deltoidea, Astrocaryum murumuru) into two transects of 2.5 and 4.0 ha, while Hart (1995), in the D. R. Congo, added seeds of two caesalps (Gilbertiodendron dewevrei, Julbernardia seretii) to several plots at seven well-separated sites. In Borneo, Curran and Webb (2000) placed seeds of a dipterocarp (Shorea stenoptera) within two 100-ha sites. The latter two studies involved mast fruiting species.

A predominant feature of forests, and those of the tropics in particular, is the frequent occurrence of local canopy disturbances caused by fallen trees (or parts of them), which create gaps in the canopy of varying sizes and shapes (Watt 1947, Shugart 1984, Denslow 1987, Richards 1996, Whitmore 1998). For many tree species these transient open habitats allow for successful regeneration and adult replacement (Watt 1947, Hartshorn 1978, Shugart 1984, Denslow 1987). However, both seed predation and seedling herbivory may be more intensive in gaps compared to neighboring closedcanopy conditions, and also dependent on local conspecific adult neighborhoods (Sork 1987, Schupp 1988, 1995, Osunkjoya et al. 1992, Schnurr et al. 2004, Norghauer et al. 2006, 2008), possibly countering the beneficial effects of light. While none of the four largescale studies mentioned above showed how canopy cover interacted with seed predation at the population level, they did highlight the importance of considering scale-dependent effects, especially for masting species.

Tree species that have evolved population-wide and synchronous reproductive events two or more years apart are able to have well-above-average abundances of seeds on these occasions (Janzen 1974, 1978, Kelly and Sork 2002). This masting behavior is thought to reduce the impact of seed predation on the tree population by satiating enemies and helping proportionally more seedlings to establish than in non-masting years (Janzen 1969, 1971, 1978, Silvertown 1980, Sork et al. 1993, Hulme and Benkman 2002). Masting appears also to be intimately linked to tree resource physiology, climate, and ectomycorrhizas (Sork et al. 1993, Kelly and Sork 2002, Henkel et al. 2005, Newbery et al. 2006a). Seed predators may have little consequence for adult recruitment, though, if most of the seeds they eat are likely to die from other causes operating at later stages of development (Harper 1977). Even in the absence of strong negative density dependence (e.g., Harms et al. 2000), sufficiently disparate levels of species-specific seed predation appear to promote tree species coexistence (Howe and Brown 2001, Paine and Beck 2007). Furthermore, few field studies to date have manipulated levels of seed consumption and/or examined seed fate in response to multiple biotic agents, and none - to our knowledge - has followed these under varying levels of canopy cover replicated across a reasonably large area of forest $\left(>1 \mathrm{~km}^{2}\right)$, and then also linked them to subsequent seedling dynamics and herbivory (Schupp and Fuentes 1995). Adding seeds beyond the range of conspecific seed shadows is another valuable way to investigate density-dependent processes and satiation effects on predators. Thus, to quantify the role of seed predation in forest dynamics more fully, variation in canopy cover needs to be incorporated at the appropriate scale.

Another crucial aspect of predator satiation with implications for understanding the evolution of masting is whether large seed crops produced in the same year and/or dispersed in the same period lead to an "apparent mutualism" or "apparent competition" between prey species (i.e., the trees' seeds) in the short term (Holt and 
Lawton 1994, Chaneton and Bonsall 2000, Kitzberger et al. 2007). In the former, when one or both prey densities increase, the other or both benefit from increased satiation facilitating escape from shared seed predators who cannot respond numerically to greater food resources. In the latter, a negative indirect interaction occurs when one or both species' increased local abundance makes the other or both prey species more vulnerable to shared predators (Holt and Lawton 1994). These community level, predator-mediated interactions are often overlooked in both studies of masting and Janzen-Connell effects, despite their potential relevance to each (Schnurr et al. 2002, Kwit et al. 2004, Kitzberger et al. 2007).

We report, accordingly, on a large-scale seed predation experiment in primary lowland rain forest at Korup, Cameroon (western Central Africa) using two canopy-emergent trees: Microberlinia bisulcata and Tetraberlinia bifoliolata (Caesalpiniaceae). Both are grove-forming species and dominate locally with a third species, Tetraberlinia korupensis (Newbery et al. 1998). Whereas $T$. bifoliolata and $T$. korupensis are regenerating well, $M$. bisulcata is not (Green and Newbery 2001a, b, Green and Newbery 2002, Newbery et al. 2006b). Recent work showed that M. bisulcata seedling recruitment at Korup was limited by strong density dependence in the brief fallen-seed-to-seedling transition, whereas it was strongly seed limited for $T$. bifoliolata (Norghauer and Newbery 2010). In the parallel study (here), at a time in 2007 when both species were masting, we made seed additions of the two species, at replicated pairs of understory and canopy locations across our 82.5-ha grove plot, with and without mammal exclusion; and we supplemented this with a comparison with locations outside the grove. Seed fate was evaluated and seedlings followed for over 2 yr. A simple matrix model explored the potential influence of seed predation on tree population dynamics.

Our study asked six questions with regard to $M$. bisulcata and T. bifoliolata: (1) What is the intensity of post-dispersal seed predation by small mammals relative to other enemy guilds for each species? (2) How do the species' seed fates compare in terms of seedling survival and growth, and levels of herbivory? (3) In which ways do gaps (compared to understory) affect seed predation and seedling dynamics for them? (4) Are their seed fates and seedling establishment similar inside and outside of the grove? (5) Is there evidence of adult-neighborhood and scale-dependent effects upon seed predation and seedling dynamics? (6) Could seed predation regulate local population dynamics and thereby contribute to tree species coexistence at Korup?

\section{Methods \\ Study site}

The study was conducted in primary lowland tropical rain forest in and around the permanent 82.5-ha "Pplot" situated in the southern part of Korup National
Park, in southwest Cameroon $\left(5^{\circ} 10^{\prime} \mathrm{N}, 8^{\circ} 50^{\prime} \mathrm{E}, 50-150\right.$ $m$ above sea level; Newbery et al. 1998). In this part of the Park, three groves of Microberlinia bisulcata, of dimensions $\sim 0.5-2.5 \mathrm{~km}$ across, occur in an otherwise species-rich mosaic of forest (Newbery and Gartlan 1996, Newbery et al. 2004). The P-plot lies within the northernmost grove. This emergent $M$. bisulcata, along with the two Tetraberlinia spp., co-dominate an irregular upper canopy $(25-40 \mathrm{~m})$, which lies above a lower, more uniform one $(\sim 20 \mathrm{~m})$ and an understory that are both much richer in woody plant species (D. M. Newbery and X. M. van der Burgt, unpublished data). The soils drain well and are nutrient poor (Newbery et al. 1997). Rainfall ( $\sim 5100 \mathrm{~mm} / \mathrm{yr}$, on average) is strongly seasonal, with a long wet period from March to November that peaks in July-August, and a shorter dry period from December to February, which often has $<100 \mathrm{~mm}$ of rain (Newbery et al. 1998, 2004, 2006a). As one of the last intact remnants of the Atlantic coastal forest of central Africa, Korup has considerable conservation value (Gartlan 1992).

\section{Study species}

The trees Microberlinia bisulcata A. Chev. and Tetraberlinia bifoliolata (Harms) Hauman, along with the third species, T. korupensis Wieringa (Caesalpiniaceae) together made up $48 \%$ of trees $\geq 50 \mathrm{~cm}$ (87\% of the trees $\geq 100 \mathrm{~cm}$ ) stem diameter (diameter at breast height, $\mathrm{dbh}$, or above buttresses) in the P-plot on its set-up in 1991 (Newbery et al. 1998). This translated to $61 \%$ of the total basal area (trees $\geq 50 \mathrm{~cm}$ ). Relative abundances varied markedly with increasing size. Although $M$. bisulcata remains scarce in size class $1-10 \mathrm{~cm}$ dbh, representing $<5 \%$ of all stems, compared to $62 \%$ for $T$. bifoliolata and $33 \%$ for T. korupensis, it accounted for $18 \%$ of stems $\geq 50 \mathrm{~cm}$ diameter compared to $12 \% \mathrm{~T}$. bifoliolata and $11 \%$ T. korupensis (stems $\geq 100 \mathrm{~cm}: 65 \%$, $15 \%$, and $17 \%$, respectively; Newbery et al. 1998). A recensus of the plot in 2005 recorded similar values (stems $\geq 50 \mathrm{~cm}: 18 \%, 10 \%$, and 14\%, respectively; D. M. Newbery and X. M. van der Burgt, unpublished data). The three species are ectomycorrhizal (Newbery et al. 1988). They have a common 2-3-yr mast fruiting cycle, although masting is not always concurrent for all three species (Newbery et al. 2006a). A case in point is 2007: $M$. bisulcata and T. bifoliolata masted, but T. korupensis did not and thus went unstudied.

Microberlinia bisulcata (hereafter just Microberlinia) is a large, moderately long-lived canopy-emergent tree that forms extensive buttresses (Newbery et al. 2009), whereas Tetraberlinia bifoliolata (hereafter just Tetraberlinia) does not grow as large as Microberlinia and forms rather indiscriminate buttresses $(<1.0 \mathrm{~m}$ tall or long). Both species produce discoid seeds (Fig. 1A and B) that are ballistically dispersed from twisting legume pods on intermittent sunny days in July-September. While similar in surface area, Tetraberlinia seeds are thicker, and thus heavier, than those of Microberlinia 
(dry mass means \pm SE: Tetraberlinia, $1.57 \pm 0.02 \mathrm{~g}$; Microberlinia, $0.64 \pm 0.02 \mathrm{~g}$; Green and Newbery 2001a; see Fig. 1B). Seeds of both species germinate very fast once wetted by rain; neither produces a seed bank.

Newly germinated Microberlinia seedlings typically have four paripinnate compound leaves of 8-24 opposite leaflets. Small seeds sometimes produce only three leaves whereas large seeds may yield up to six leaves (Fig. 1C). Newly germinated Tetraberlinia seedlings always have two compound leaves, each consisting of two leaflets; for this species, variation in seed size translates into height and leaf area differences among individuals (J. M. Norghauer, personal observations). For the purpose of our experiment, each Tetraberlinia leaflet was counted as an individual leaf (Fig. 1D). Seedlings of both species have exposed cotyledons raised above the ground; i.e., they are phanerocotylar-epigeal (Garwood 1996). Microberlinia (known locally as African zebrawood or zebrano) is a critically endangered tree endemic to Cameroon/Nigeria (IUCN 2000), which unfortunately still lacks CITES (Convention on International Trade in Endangered Species of Wild Fauna and Flora) protection. Its timber remains highly valued.

\section{Experimental design}

The 82.5-ha plot measures $1650 \mathrm{~m}$ (east to west) by $500 \mathrm{~m}$ (north to south) and contains 330 subplots $(50 \times$ $50 \mathrm{~m}$ each, see grids in Appendix A) each marked by plastic posts. We used a stratified random block design with a nested hierarchical structure to both maximize interspersion and minimize spatial heterogeneity, and to achieve an adequate representation at the population level (Appendix A). The final 50-m-wide column of 10 subplots at the western end of the plot was omitted from the study. The remaining 320 subplots were divided into 32 blocks, each covering 2.5 ha and consisting of 10 subplots (i.e., $100 \times 250 \mathrm{~m}$ ). Within each 2.5 -ha block, two subplots were randomly selected, totaling 64 subplots for possible experimentation with the constraints that they could neither be adjacent to one another (though two of them could share a corner post) nor link with one or more subplots in an adjacent block to form a chain. Such cases were rare though $(n=6$ and $n=2$ subplots, respectively), and they were substituted by the next randomly selected subplot. Field inspection of the resulting 64 subplots found most of them to be suitable but 16 were either very rocky, had steep terrain, or were overly wet, to be used (Appendix A).

The remaining 48 subplots were each subdivided into $5 \times 5-\mathrm{m}$ areas $(n=100)$, and one of these randomly selected as the understory location. From this location, we searched for the nearest canopy gap that met the criteria of having tree-fall debris present with at least 10 $\mathrm{m}^{2}$ of vegetation $<2 \mathrm{~m}$ tall and a canopy openness of $\geq 6 \%$ (as measured with a hand-held spherical densitometer). To avoid a possible ripple effect of gaps relative to their counterpart understory locations, caused by the search being pushed mostly westward across the P-plot, on each day we began our searches in different parts of the plot. Each understory-gap pair of locations was henceforth referred to as an experimental block $(n=48)$. Four selected gaps fell outside the plot but were within $50 \mathrm{~m}$ of its edge; and two of 48 blocks had their shade locations shifted to an adjacent subplot to fall within $75 \mathrm{~m}$ of the nearest gap (Appendix A).

In each experimental block, two $1.25 \times 1.25-\mathrm{m}$ quadrats were set up at each of the understory and gap locations; for each pair of quadrats, one was randomly assigned to be a control and the other a treatment that excluded small terrestrial mammals. This latter effect was achieved using a fence made of chicken wire (hexagonal holes of $1 \times 3 \mathrm{~cm}$ ), the base of which was carefully embedded $5 \mathrm{~cm}$ into the ground so that it stood $45 \mathrm{~cm}$ tall along the quadrat perimeter. Wooden stakes secured the fences at the vertices, and smaller wood stakes were used to mark corners of the control quadrats. Fully closing cages would not have been feasible because of many woody stems $>50 \mathrm{~cm}$ tall in the forest, especially in gaps. Additionally, they would have prevented litter reaching the ground, and required even more material to construct proper controls with roofs only. We reasoned too that small mammals (e.g., rodents, duikers) would likely not expend unnecessary energy to reach fenced-in seeds, especially during a masting event when seeds were abundant everywhere within the plot. Nevertheless, we purposely placed the barbed edge of the fence (i.e., where the mesh roll was cut in half) upward to deter curious mammals; a pilot test indicated that the exclosures were effective. On 30 August 2007 we added piles of 8-16 seeds of Microberlinia and Tetraberlinia to fenced quadrats in 16 subplots, split between understory and gaps. After four days, all seeds were still accounted for, and many had already germinated. Distance between the paired treatment quadrats in the understory locations were $\sim 3.75 \mathrm{~m}$ edge to edge (i.e., $5 \mathrm{~m}$ center-to-center) but in canopy gaps it varied from 0.5 to $5 \mathrm{~m}$ because of debris, large tree limbs, thick woody vines, etc, even though paired quadrats were situated as much as possible in the centers of gaps.

Once the controls and exclosure quadrats were positioned and installed (1-5 September 2007) in all 48 pairs of understory-gap locations, seeds were ready to be sown. Earlier, on two to three sunny days in late August, freshly fallen Microberlinia and Tetraberlinia seeds were collected from three adults each and kept air dry in a camp house to stall fast germination triggered by moisture. Seeds were checked twice for viability and insect predation (i.e., small holes) and germination (indicated by cracking of the seed coat). They were thoroughly mixed before additions were made in the field. To each quadrat we added 16 relatively large seeds, eight per species in a checkerboard fashion using a grid array (see Appendix A). Undamaged, viable, nongerminated seeds were added onto the litter in a precise way by crossing two $1.25-\mathrm{m}$ long sticks marked at 


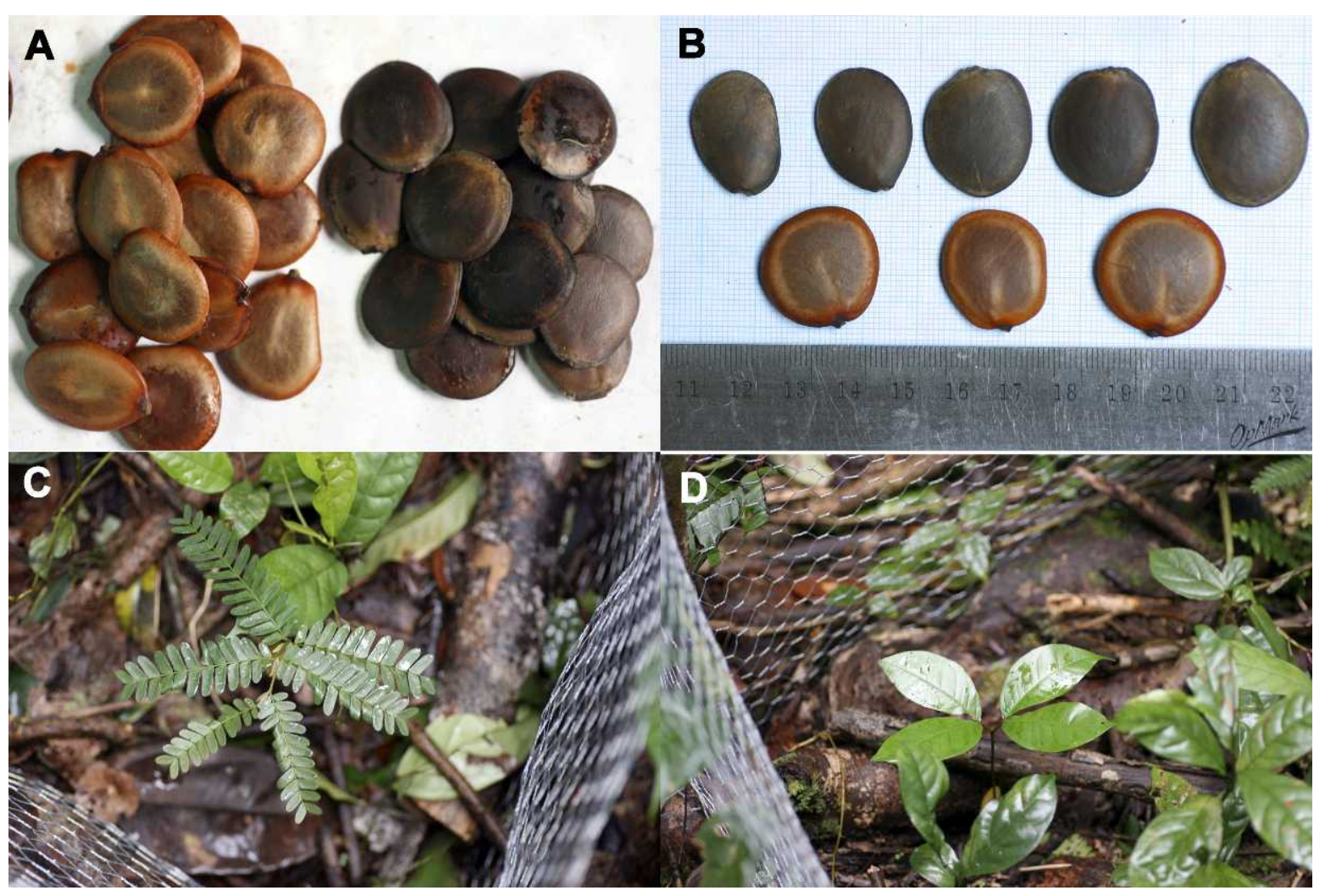

FIG. 1. Seeds and newly germinated seedlings of the two masting rain forest tree species studied at Korup National Park in Cameroon. In panels (A) and (B), respectively, are shown the light brown seeds of Tetraberlinia bifoliolata beside the dark brown seeds of Microberlinia bisulcata. In panel (C) is shown a new Microberlinia bisulcata seedling protected from small mammals in a fenced exclosure, with its pinnate leaves fully expanded; and in panel (D), a new Tetraberlinia bifoliolata seedling, also protected, with its two compound leaves (two large leaflets per leaf). Photo credits: J. M. Norghauer.

intervals of $15,47,79$, and $111 \mathrm{~cm}$ that were laid out within each quadrat. In this way, then, seeds were placed at marked intersections, $\sim 32 \mathrm{~cm}$ apart and $\sim 15 \mathrm{~cm}$ from the quadrat perimeter, and did not require individual marking. Quadrat vegetation was not weeded at any time during the experiment. The seed density added was equivalent to 5 seeds $/ \mathrm{m}^{2}$, which corresponds to densities typically found $15-25 \mathrm{~m}$ away from trees with no other conspecific neighbors in that direction. In fact, seed densities were likely greater at this distance where trees were clustered because of overlapping seed shadows.

To distinguish experimental seeds from natural seeds already dispersed, and to maintain a similar density across treatments, we cleared quadrats of any Microberlinia and Tetraberlinia seeds in the litter before additions were made. Seeds were tossed outside of quadrats haphazardly and newly germinated seedlings transplanted outside of them whenever feasible. To avoid potential cross-infection from in situ pathogeninfested seeds to experimental seeds, one person removed these ambient seeds by hand, whereas another made the seed additions. Seed additions in the P-plot were made on 6-10 September 2007, which corresponded to an overlap in the dispersal periods of both tree species: more specifically this time was near the peak in seed-fall of Tetraberlinia, but more toward the end of that for Microberlinia, which began its dispersal earlier in August than Tetraberlinia.

\section{T-design for Microberlinia grove effects}

To determine the fate of seeds in the absence of Microberlinia adult neighbors, we selected the 15 subplots closest to the perimeter of the plot and paired them with an understory-gap block location outside the adult Microberlinia grove. We call this a "T-design" because a subset of the 48 subplots were extended perpendicular to the P-plot boundary and paired beyond it to 15 pseudo-subplots outside the grove. The distance from the outermost side of each of the 15 subplots to the edge of the Microberlinia grove outside the plot was measured, and then doubled onward to situate the understory locations outside the grove. The distances between inside and outside subplots ranged from 60 to $250 \mathrm{~m}$ and thus $120-500 \mathrm{~m}$ between these 15 "in" and 15 "out" subplots. Paired treatment quadrats at these 15 out subplots and their nearest suitable gap locations were installed 11-14 September 2007 following the same protocol described above for inside the plot.

In sum, 4032 seeds were added at 63 experimental blocks in the forest: split first among the two levels of 
canopy cover (understory vs. gap), then nested within each canopy level, split again between protected vs. unprotected from mammal predators, and in the latter, split once more between Microberlinia and Tetraberlinia seeds. For the plot sample (48 blocks), the design can be described as a split-split plot experiment, and for the Tdesign sample (15 blocks), as a split-split-split plot experiment (Federer and King 2007). Ideally, we might have replicated across many Microberlinia groves to properly test for grove-related effects, however this was not possible logistically; thus the T-design described here is in fact pseudo-replicated at this scale, and used only one grove (or two sub-groves) as delineated by Newbery et al. (2004).

\section{Seed fate}

The fate of experimental seeds was assessed in the period 12-27 October 2007. Each seed was assigned to one of six categories: (1) seed established as a rooted seedling (Fig. 1C and D); (2) seed missing entirely (i.e., removed and presumed eaten by small mammals); (3) seed eaten in situ by invertebrates (Fig. 2A-F); (4) seed remnants present with signs of white fungus attack and/ or its spherical orange-brown spores (Fig. 2I-L); (5) seed partly eaten by invertebrates but also showing signs of white fungal attack (Fig. 2G and $\mathrm{H}$ ); or (6) seed germinated that may or may not have established, but was clipped and/or uprooted from soil. Seeds not in their precise sowing location yet found within $\sim 15 \mathrm{~cm}$ radius were assumed to be of those added experimentally. Otherwise, the quadrat was then searched thoroughly to locate any seed(s) still unaccounted for that possibly moved beyond $15 \mathrm{~cm}$ radius (this seldom the case, however). The grid technique for relocating seeds was effective because Microberlinia and Tetraberlinia seeds germinate quickly, in a matter of a few days, enabling them to anchor in the moist soil, and thus leaving little time to get moved about.

We assumed that small mammals ate missing seeds immediately or soon after, and that these seeds had been negligibly damaged from insects or pathogens prior to their removal from quadrats. It is unknown whether scatter hoarding of seeds occurs in our forest, though perhaps this is unlikely given that Microberlinia and Tetraberlinia have relatively small seeds compared to other tropical masting tree species (Jansen et al. 2004). Seed caching went unobserved in the present study, but one instance of it was noticed at a nearby site (Isangele Road) as betrayed by a tight clump of six newly germinated seedlings (J. M. Norghauer, personal observations). At eight quadrats where we could not distinguish experimentally added seeds from those naturally dispersed, all of the 9 or 10 seeds in total per species, irrespective of origin, were assigned to categories and their proportions used: in all other quadrats seed fate proportions were based on eight seeds per species (see Data analysis). Newly germinated seedlings were marked with toothpicks.

\section{Seedling dynamics and leaf herbivory}

To investigate post-establishment seedling dynamics, all quadrats at all locations were checked on 3-10 April 2008. Toothpicks were relocated and live established seedlings were marked with numbered wire-stake flags ( $\sim 15-20 \mathrm{~cm}$ tall). Seedlings were then measured for relaxed height and leaf number, and scored for leaf damage on a scale with seven levels: $<1 \%, 5 \%, 10 \%$, $25 \%, 50 \%, 75 \%$, and $90 \%$ area missing (done by one person). To track leaf production, an ink mark was made on the stem at the point(s) where the most recent leaf was attached. About 14 months after seeds were sowed, quadrats were re-censused for seedling mortality, height, and leaf number, and leaf damage ( period of 2330 November 2008). Because of the much larger sample of leaves in this second census, we simplified the scoring of leaf damage into five classes: $<5 \%, 5-<20 \%, 20-$ $<50 \%, 50-<75 \%$, and $>75 \%$ area missing. At this time, we also recorded number of new leaves produced and number of old ones retained. The accuracy of our damage assessments by class was tested using 40 leaves of Microberlinia: it was strongly correlated with the actual leaf area missing in terms of the summed areas of leaflets absent $\left(r^{2}=0.90, P<0.001\right)$. The third and final mortality census of the experimental seedlings was carried out in the period 18-22 November 2009, almost 27 months after seeds were sowed in early September 2007. Relaxed height was also recorded, as was leaf number, but levels of leaf damage not. We were unable to confidently record numbers of new leaves since the last census (November 2008) because most of the stem marks had faded.

\section{Neighborhood effects}

Distance and compass bearing from the understory to its counterpart gap location were measured for all experimental blocks, as was distance from paired quadrats to the nearest northeast corner post demarcating a subplot. In both cases, distances were taken from the point midway between paired quadrats in either understory or gap locations. The mean $( \pm S D)$ distances between understory to gap edge locations for the 48 and 15 experimental blocks in and out of the Pplot, respectively, were $36.9 \pm 14.9 \mathrm{~m}$ (median $=37.8$ $\mathrm{m}$, range $11-68 \mathrm{~m})$ and $45.9 \pm 20.3 \mathrm{~m}($ median $=42.5$ $\mathrm{m}$, range $=21-87 \mathrm{~m}$ ). Distance and bearing from understory locations to gaps and to the nearest NE post were measured and used to map their coordinates in the P-plot. Mean $( \pm \mathrm{SE})$ nearest-neighbor distance between understory locations was $94.2 \pm 3.5 \mathrm{~m}$ (median $=92.0$ $\mathrm{m}$, range $56-152 \mathrm{~m}, n=48)$, and between gap locations, $93.8 \pm 3.2 \mathrm{~m}($ median $=92.6 \mathrm{~m}$, range $=44-169 \mathrm{~m}, n=$ 48).

The $x, y$ coordinates of paired quadrats was calculated separately for all understory $(n=48)$ and gap locations $(n=48)$ to position them in the 82.5-ha Pplot. To evaluate the influence of current neighborhood on seed fate, we calculated two neighborhood indices. 

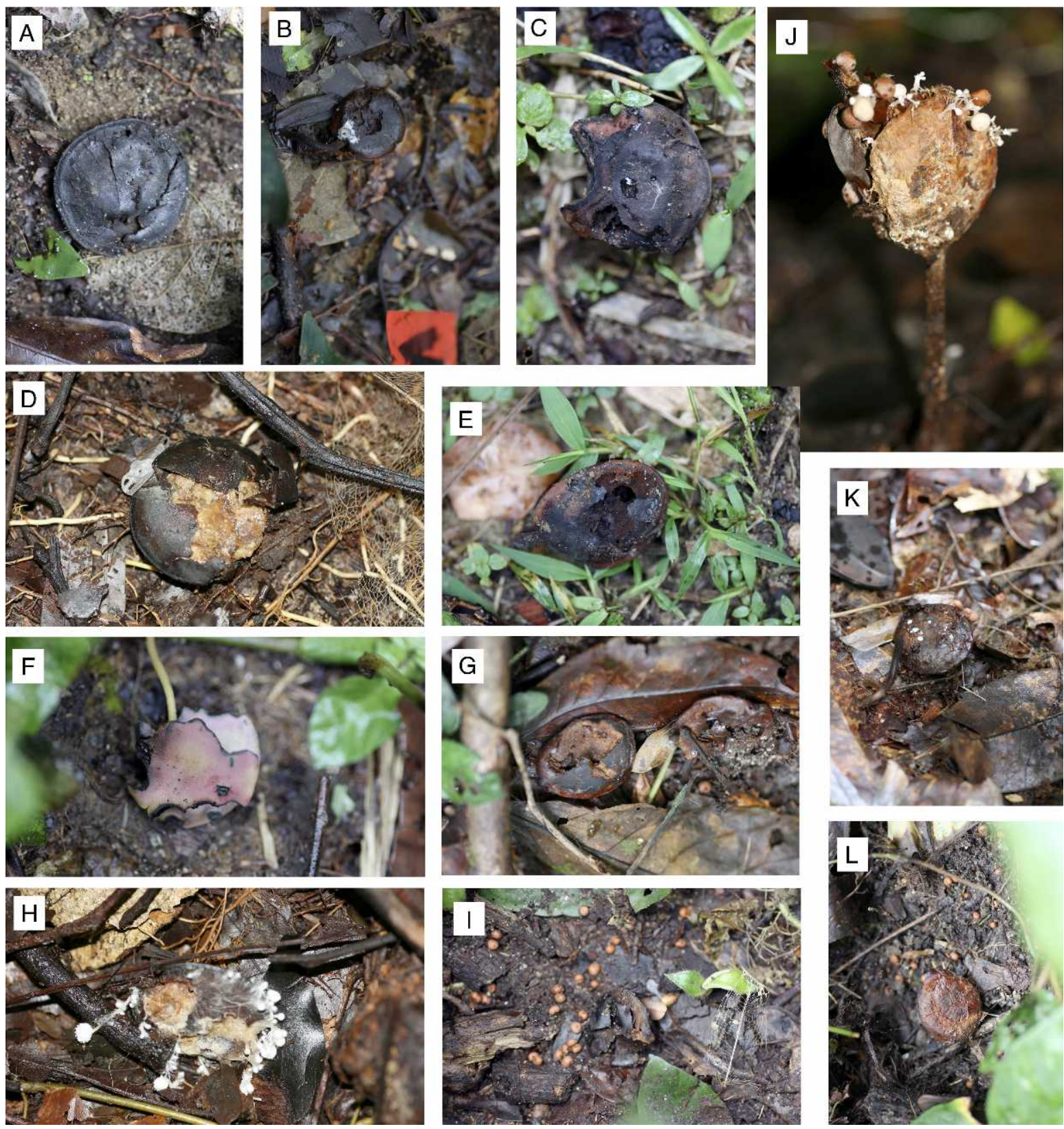

FIG. 2. Examples of invertebrate- and fungal-associated seed deaths and characteristics used to identify them in the field using seeds of Microberlinia bisulcata and Tetraberlinia bifoliolata at Korup National Park, Cameroon. Shown are Microberlinia seeds (A, B, D) and Tetraberlinia seeds (C, E, F) eaten in situ by unknown invertebrates; seeds partly eaten by invertebrates but also showing signs of white fungal attack $(\mathrm{G}, \mathrm{H})$; and seed remnants with signs of white fungus attack indicated by its fruiting body and/or its spherical orange-brown spores (I-L). Photo credits: J. M. Norghauer.

First, using tree size measures from the 2005 plot enumeration (D. M. Newbery and X. M. van der Burgt, unpublished manuscript), we derived basal area (BA $\left[\mathrm{dm}^{2}\right]$ ) sums of trees $\geq 10 \mathrm{~cm}$ diameter of Microberlinia and Tetraberlinia within a 25-m radius of each location of paired quadrats. Before summing these BA values, however, each was weighted by individual distance to the paired quadrats (tree $\mathrm{BA} /$ distance). Twenty-eight out of the 96 locations were within $50 \mathrm{~m}$ of the P-plot boundary (plus four gaps outside P-plot). For these 32 locations, for which data on T. bifoliolata stems outside the P-plot were lacking (but not Microberlinia), we searched (in April 2010) for stems $\geq 10 \mathrm{~cm}$ within a 50-m radius in the field. These stems were mapped, tagged, and measured for diameter. A second neighborhood index was measured in the field in May 2008, namely distance from each location to the nearest alive conspecific tree $(\geq 50 \mathrm{~cm}$ and $\geq 30 \mathrm{~cm}$ diameter for 

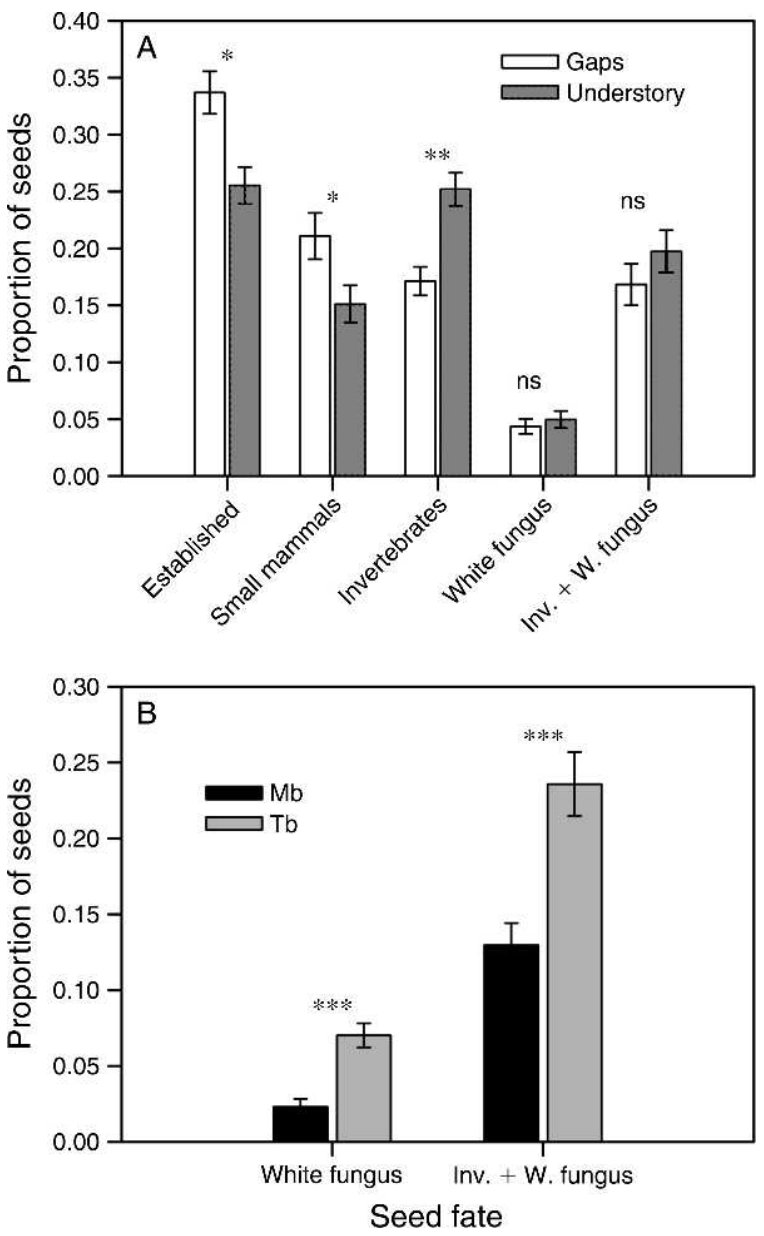

FIG. 3. Mean $( \pm \mathrm{SE})$ proportions of seeds in the P-plot in Korup National Park, Cameroon: (A) categorized into five seed fates, in canopy gaps vs. forest understory for the tree species Microberlinia bisulcata and Tetraberlinia bifoliolata combined ( $n=384$ per seed fate); and (B) for M. bisulcata (Mb) and $T$. bifoliolata $(\mathrm{Tb})$ separately in cases where seeds were attacked by a white fungus and by both invertebrates and the fungus (Inv. + W. fungus).

$* P<0.05 ; * * P<0.01 ; * * * P<0.001$; ns, not significant.

Microberlinia and Tetraberlinia, respectively) in a 75-m

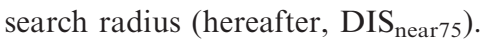

\section{Local light availability}

To quantify aspects of the local light environment of seeds and seedlings, on 9-10 January 2008, at each understory and gap location a hemispherical photo of the canopy was taken in center of each quadrat at a height of $90 \mathrm{~cm}$ (total $n=192$ in P-plot, plus another $n=$ 60 outside the grove) using a Nikon Coolpix digital camera affixed with a Fisheye lens (models 950 and FCE8, respectively; Nikon Corporation, Tokyo, Japan). These were taken under overcast sky conditions whenever possible, or early or late in the day. Photos were analyzed with Gap-Light Analyzer (GLA) software (Frazer et al. 1999) with a blue color plane using Korup site coordinates and default settings to obtain percent forest canopy openness (CO) and daily percent transmission of total photosynthetic photon flux density, measured as $\mathrm{mol} \cdot \mathrm{m}^{-2} \cdot \mathrm{d}^{-1}$ (i.e., direct + diffuse radiation; PPFD). Even though very conservative manual threshold adjustments were made by one person to achieve consistency and precision, hemi-photo software analyses tends to overestimate true values under very shaded conditions where light transmission through the canopy is $<5-10 \%$ (Chazdon and Field 1987).

\section{Data analysis}

Seed fate.-Proportions for each seed fate category except category 6 were arcsine transformed and analyzed in a split-split plot ANOVA (analysis of variance option in GENSTAT v.12.0; VSN International, Hemel Hempstead, UK). This approach is preferable to a generalized linear mixed model (GLMM) because the sample was both large and fully balanced, with the majority of proportion values between 0.25 and 0.75 so that the error distribution was close to Gaussian, and because ANOVA is more conservative in $F$ tests than the Wald statistic in REML of GLMM (Galwey 2006). In this ANOVA model, and others that follow below, the fixed effects were canopy cover (understory vs. gap), small mammal predation (control vs. exclosure), and species identity (Microberlinia vs. Tetraberlinia) with $F$ tests made on the main and interaction terms using the appropriate degrees of freedom for the error terms in each of the four strata: beginning atop with the experimental block ( $n=48$ ), followed by (1) canopy type location within block, (2) exclosure/control within location (within block), (3) species within exclosure/ control (within location within block), and (4) "unitplant" within all the higher levels. Model assumptions (normality of residuals and equal variance) were checked via diagnostics outputs in form of histograms, fitted value plots, and quantile plots. Because the five response variables were likely not independent of each other, and because MANOVA cannot adequately accommodate a multi-stratum analysis of variance, we used an $\alpha=0.025$ instead of $\alpha=0.05$ to guard against Type I errors. For an interaction term that was significant, treatment means were compared using least significant differences at the 5\% significant level, however (Galwey 2006, Federer and King 2007).

To confirm our stratified experimental design resulted in adequate sample independence for univariate responses, we used Moran's $I$ permutations $(k=5$ nearest neighbors, 999 simulations) to test for significant spatial autocorrelations in the six seed fate variables: namely the five of main interest (see $x$-axis of Fig. 3A) plus the "clipped/uprooted" fate, separately for each of the eight treatments (canopy $\times$ predation $\times$ species; giving 48 tests). Because these six variables were not independent of one another, we used a corrected value of $\alpha=0.05 / 6=$ 0.0083 . Descriptive and statistical spatial analyses were 
made in R 2.10.1 using "spatial," "spatstat," and "spdep" packages (available online). ${ }^{2}$

Seedling dynamics.-For each species, seedling survival after $\sim 1$ yr (hereafter "1-yr seedling survival") was expressed as the proportion of established seedlings in October 2007 alive in November 2008. Similarly, the probability of recruiting from seed (hereafter " 1 -yr seed survival") was expressed as the proportion of seeds sown in September 2007 alive in November 2008. This was repeated with data from the final census, so that " 2 -yr seedling survival" was the proportion of established seedlings in October 2007 still alive in November 2009, and "2-yr seed survival" was expressed as the proportion of seeds sown in September 2007 still alive in November 2009. We used a GLMM to model survival proportions per quadrat (as counts out of a total) and assumed a binomial error distribution with a logit link function with the same fixed terms and appropriate random error terms specified for the nested treatment structure. Treatment means were compared using averaged standard error of differences between them and the $t$ distribution (see Galwey 2006:130-136) with a sequential Bonferroni adjusted $\alpha$ level.

For 1-yr and 2-yr seed survival, however, because the sample was fully balanced $(n=384)$, we could again use a split-split ANOVA on the arcsine square-root transformed proportions of seeds still alive in November 2008 and 2009, and least significant differences for multiple comparisons of means.

Seedling traits.-To examine treatment effects upon seedling size, growth, and leaf herbivory, we used separate linear mixed models (LMMs) on the following response variables for seedlings alive in November 2008: (1) relaxed height, (2) number of extant leaves, (3) new extant leaves produced between April and November 2008, (4) leaf damage (in the same period for new leaves in gaps, all leaves in the understory), and (5) relative growth rate in height $\left(\mathrm{RGR}_{\mathrm{ht}}, \mathrm{cm} \cdot \mathrm{cm}^{-1} \cdot \mathrm{yr}^{-1}\right)$ based on the increment for April to November 2008. MANOVA was again unsuitable because it cannot accommodate our complex, now unbalanced, split-split blocked design. To avoid pseudoreplication here, all response variables examined were first averaged over seedlings on a per-quadrat basis, and these quadrat-level means were used in the analysis as the "replicates" (i.e., not the observational units). To meet model assumptions, response variables 1-4 were log-transformed and variable 5 was square-root transformed for the LMMs. The influence of each response value, at the quadrat level, on the fit of the model was weighted by number of seedlings in that quadrat (i.e., more weight was given to those treatment level means that were based on larger samples; Galwey 2006). Random error terms were included in the model in the same way as in other mixed models already described; we set a significance level of $\alpha=0.05 / 4=0.0125$ to correct for the four

${ }^{2}\langle$ www.r-project.com $\rangle$ simultaneous size/growth analyses on the same sample of seedlings.

For the survivors found in November 2009, we took the best performers for each species (those with maximum values per quadrat) in terms of (1) relaxed height and (2) number of extant leaves; and analyzed treatment effects with two separate LMMs. We reasoned, from a population perspective, that the best performer was the most likely to recruit into the $>10-\mathrm{cm}$ size class, and multiple adults obviously cannot recruit in such a small quadrat area (Kobe and Vriesendorp 2009). Both variables were log-transformed before analysis. For significant interaction terms, treatment means were compared using averaged standard error of differences between means and the $t$ distribution (Galwey 2006:130-136) with a sequential Bonferroni adjusted $\alpha$ level.

To compare seed fate and seedling dynamics inside and outside the adult Microberlinia grove in the Tdesign, these same analyses were made on the subsample of 15 blocks in the P-plot and their 15 counterparts outside the grove (total $=30$ pairs of gap-understory blocks).

Local adult neighborhood effects.-If post-dispersal seed predation operates in a positive density-dependent manner (i.e., one that is not liable to satiation), then the degree to which seeds are removed by small mammals and fail to become established seedlings should increase with either local density of conspecific trees and/or proximity to them. If these predators are liable to satiation, however, then on average the beneficial effect of their exclusion upon seed removal and seedling recruitment should decline with increasing density of and/or distance from adult trees. Moreover, canopy cover and disturbance may moderate differences in the relative strength of an effect (the effect size), which adds another facet to the underlying set of processes.

For the two species, and for understory and gap locations ( $n=48$ each), separately were found the sizes of (1) a protection effect, defined as the difference in counts of established seedlings in the exclosure treatment minus control; and (2) a predation effect, defined as counts of seeds removed in the control minus exclosure treatment. For the protection effect, a fair number of negative values occurred ( $n=49$ out of 192), meaning that at these locations more seedlings established in the control than in the exclosure treatment. For the predation effect, one gap was an outlying case, with values of -6 and -5 : these plus six cases of -1 in gaps or understory were omitted, as the overall exclusion effect was somehow compromised at these locations. For each type of effect times each of the four data sets (canopy type $\times$ species), four regressions were made (two for conspecific $\mathrm{BA}_{\mathrm{dis} 25}$ [log-transformed], and two for

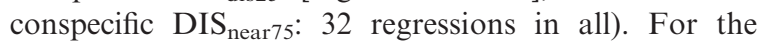
protection effect a Gaussian error term was suitable; for the predation effect it was binomial. Percent canopy openness (mean of control and treatment at a location) 
was included as a covariate. Satisfying model assumptions for regressions of Tetraberlinia seed fates in gaps as function of $\mathrm{BA}_{\mathrm{dis} 25}$ was improved by including untransformed $\mathrm{BA}_{\mathrm{dis} 25}$ of Microberlinia as a third predictor. To control for family-wide type-I error rate in these analyses, a sequential Bonferroni approach was used.

Population matrix projections.-For this exercise, because seedling growth in the understory was negligible for both species, we used dynamics data gathered in this experiment from gaps only. A stage-based life table was first constructed for each tree species (described in Appendix K). These were used to calculate vital rates for a six-stage matrix, with and without small mammal protection, separately for each species ( $n=4$ matrices in total, see Appendix L). The dominant eigenvalue for each matrix, equivalent to the finite rate of population increase $(\lambda)$, was calculated using "popbio" software (see footnote 2).

\section{Results \\ Local light availability}

Using very conservative thresholds, means $( \pm \mathrm{SD})$ for $\mathrm{CO}$ across the forest gaps and understory quadrats in the P-plot samples were, respectively, $5.91 \pm 1.2 \%$ $($ median $=5.8 ;$ range $=3.7-10.1 \%)$ and $3.37 \pm 0.58 \%$ (median $=3.4$; range $=2.0-5.8 \%$ ). Because natural gap formations were used, the greater variability in gap CO was expected, as was its mean being significantly greater than in nearby understory locations (paired $t$ test on logtransformed values, $t=21.3$, df $=95, P<0.0001)$. Generally, habitat differences were more pronounced when light transmission (total direct + diffuse) was indirectly evaluated. For gaps, mean PPFD (13.23 \pm $2.79 \%$ ) was more than double that at understory locations $(5.95 \pm 1.625 \% ; t=23.35$, df $=95, P<$ 0.0001).

The 15 canopy gaps located outside of the Microberlinia adult grove had a mean $\mathrm{CO}$ and PPFD of $5.70 \pm$ $1.3 \%$ and $13.0 \pm 3.1 \%$, respectively. These values were not significantly different from the 15 gaps inside the Pplot to which they were matched in the T-design (CO and PPFD, respectively, $5.96 \pm 0.90 \%$ and $13.4 \pm 2.3 \%$; two-sample $t$ test with unequal variances, $\mathrm{df}=52, P=$ 0.36 and $\mathrm{df}=53, P=0.57$ for $\mathrm{CO}$ and PPFD, respectively). However, the canopy was slightly more open above understory quadrats inside than outside the grove (CO: $3.60 \pm 0.45 \%$ vs. $3.31 \pm 0.35 \%$, respectively; $t=2.74, \mathrm{df}=54, P=0.008)$ although this did not translate into a significant difference in PPFD $(t=1.74$, $\mathrm{df}=56, P=0.087)$. In sum, gap light levels were not different inside and outside the Microberlinia grove, but understory light levels were marginally higher inside the grove.

\section{Seed fates}

Overall, seed predation by small mammals and invertebrates was more common in Microberlinia $(24 \%$ and $25 \%$ of total seeds, respectively; Appendix B), accounting for nearly half of all seed losses. By contrast, seed predation by small mammals was less than half as great on Tetraberlinia (11\%) as most of its seed losses were due to joint attacks by invertebrates and the white fungus (23\%), or by invertebrates only (8\%) (Appendix B). Yet six weeks after seeds were added a similar proportion of seeds, $27.5 \%$ and $31.7 \%$, had established as seedlings for Microberlinia and Tetraberlinia, respectively ( $P=0.74$, Fig. 3A). An additional $2.9 \%$ and $2.1 \%$ of newly germinated Microberlinia and Tetraberlinia seedlings, respectively, had their stems clipped by unknown animals, whereas slightly more $3.6 \%$ and $4.4 \%$, respectively) were found in a non-rooted and/or uprooted state. The latter fate plus clipping was widespread and amounted to similar seed deaths of $6.3 \%$ and $6.5 \%$ for Microberlinia and Tetraberlinia, respectively (recorded at least once at 46 of the 48 experimental blocks). Non/up-rooted and clipped seedlings were found in both controls and exclosures to the same extent (main effect, $P=0.81$ ): non-lignified stems were probably clipped by large grasshoppers. (Details of the statistical tests in this section are found in Appendices C and D.)

Canopy cover influenced Microberlinia and Tetraberlinia seed losses to vertebrates and invertebrates in opposite ways (main effect of canopy, $P=0.006$ and $P=$ 0.003 , respectively). On average, the proportion of seeds missing of both species was $39 \%$ higher in canopy gaps than in closed forest understory, whereas conversely $47 \%$ more seeds were killed by invertebrates in the understory than in gaps (Fig. 3A). Canopy cover, however, had apparently little influence on seed susceptibility to either white fungus attacks or joint fungus and invertebrate attacks, but species identity had a highly significant effect upon these two seed fates (both $P$ values $<0.001)$. Although among seed fates the least frequent was attacks by white fungus only (Fig. 3A), Tetraberlinia seeds were three times as vulnerable to fungus-only attacks than Microberlinia, and nearly twice as vulnerable to joint attacks by fungus and invertebrates (Fig. 3B). Irrespective of species identity and canopy cover, however, the proportion of seeds with joint fungus and invertebrate attacks was significantly greater in the exclosures compared to controls (predation term, $P<0.001$, back-transformed means of arcsine square-root proportions were 0.360 vs. 0.263 ).

The seed fates of the two tree species differed depending on whether or not they were protected from small mammals. Not surprisingly, very few seeds were removed from the exclosures and the vast majority was removed from controls; but in the latter more than twice as many Microberlinia than Tetraberlinia seeds were depredated by vertebrates (predation $\times$ species term, $P<0.000001$; Fig. 4A). While in the controls Microberlinia and Tetraberlinia appeared equally susceptible to invertebrate predation, in the exclosures a third less Tetraberlinia seeds were killed in this way than Microberlinia seeds (predation $\times$ species term, $P=0.002$; Fig. 

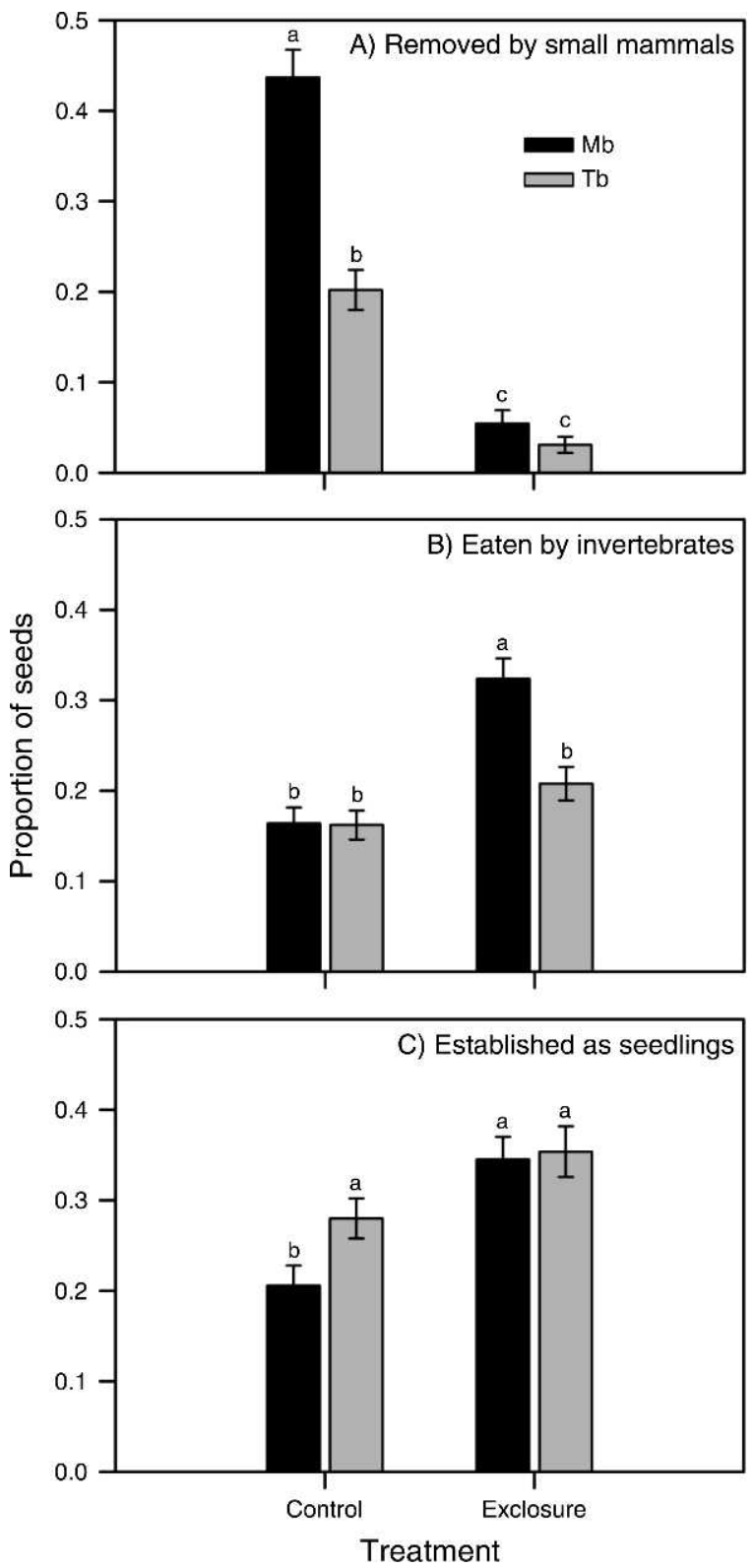

FIG. 4. Mean $( \pm \mathrm{SE})$ proportions of Microberlinia bisulcata $(\mathrm{Mb})$ and Tetraberlinia bifoliolata $(\mathrm{Tb})$ seeds in the P-plot in Korup National Park, Cameroon, in the control vs. exclosures that were depredated by (A) small mammals and (B) invertebrates, and (C) that established as seedlings in October 2007. For all three seed fates, $n=96$ per predation $\times$ species combination. Means with different lowercase letters are significantly different at $P<0.05$.

4B). A weaker interaction was also evident for seedling establishment $(P=0.019)$, which was similar between Microberlinia and Tetraberlinia in the exclosures, yet significantly lower in the controls only for Microberlinia seeds (Fig. 4C).

The same patterns in seed fates as affected by canopy cover, predation, and species already described were also largely found in the analysis of the T-design, an important difference being that the effect of canopy cover on seeds established and depredated by small mammals was weaker $(P=0.069$ and 0.082 , respective1y). Three novel results emerged, however. (1) Small mammals depredated marginally significantly more Microberlinia and Tetraberlinia seeds outside than inside the grove ( $P=0.078$; Fig. 5A). (2) The incidence of white fungus attack, and of fungus plus invertebrate attack, diminished substantially outside the grove to, respectively, less than half and one third of the mean proportions of seeds observed inside it (Fig. 5A). (3) Protection from small mammals significantly increased seedling establishment outside the grove (by 40\%), but not inside it, compared to controls ( $P=0.031$, Fig. 5B).
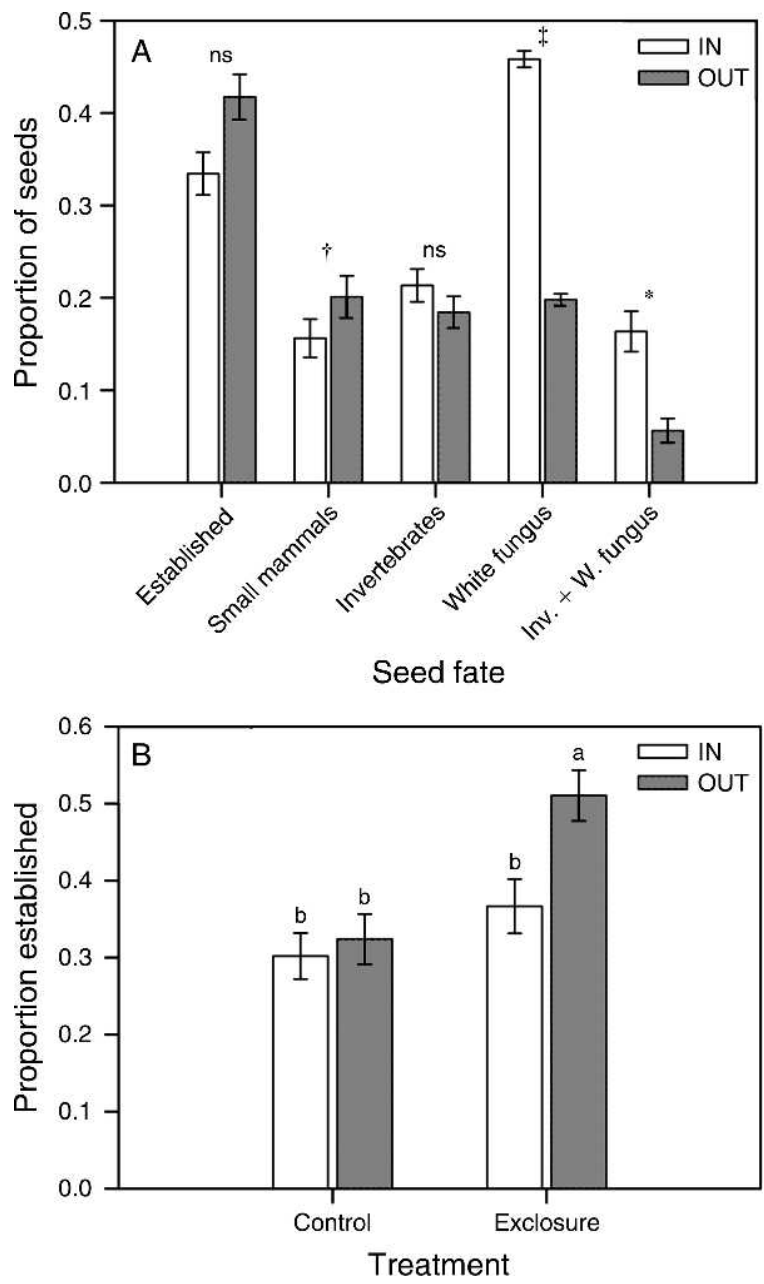

FIG. 5. Mean ( \pm SE) proportion of seeds (A) assigned to five seed fates for inside (IN) and outside (OUT) the Microberlinia bisulcata grove in Korup National Park, Cameroon, for both M. bisulcata and Tetraberlinia bifoliolata in controls and exclosures, total $n$ per seed fate $=240$, or $n=120$ for IN vs. OUT (ns, $P>0.10 ; \dagger P<0.1 ; * P<0.05 ; \ddagger P<0.005$ ); and (B) that established in controls and exclosures inside and outside the grove, irrespective of canopy cover. Means with different lowercase letters are significantly different at $P<0.05$. 


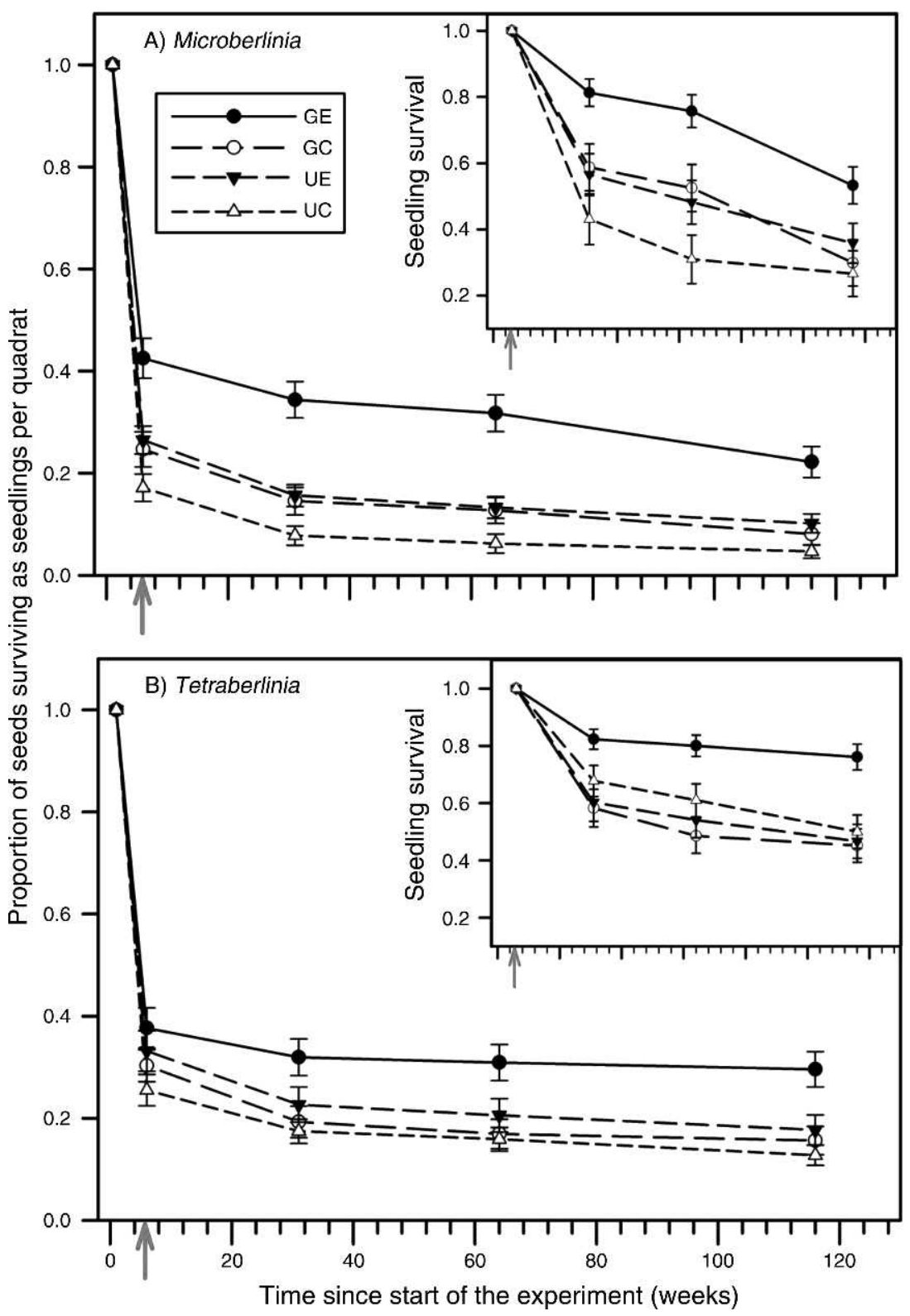

FIG. 6. Sown seeds that established as seedlings (6 weeks) and their survivorship through to April 2008 (31 weeks), November 2008 (64 weeks; i.e., 1-yr seed survival), and November 2009 (116 wks; i.e., 2-yr seed survival) in the P-plot in Korup National Park, Cameroon, for (A) Microberlinia bisulcata and (B) Tetraberlinia bifoliolata in controls and exclosures in canopy gaps (GC, GE respectively) and the forest understory (UC, UE respectively). Symbols are means $( \pm \mathrm{SE})$ for each treatment combination $(n=48)$. The experiment was set up in early September 2007 (time $=0)$; the gray arrows indicate the date on which fates were assessed six weeks later in October 2007. The insets depict seedling survival (proportion) from this point onward using the mean ( \pm SE) proportion of seedlings that established in October (same time axis). Sample sizes are unbalanced because of some quadrats where all of a species seeds died prior to establishment. For Microberlinia, $n=34$ and 33 for controls, and $n=42$ and 39 for exclosures in gaps and understory, respectively. Likewise, for Tetraberlinia, $n=41$ and 40 for controls, and $n=37$ and 37 in gaps and understory.

\section{Seed and seedling survival}

In the main plot, gaps and understory also had a differential effect on survival of seeds after they became established as seedlings (Fig. 6, Appendix E). Whereas the two species responded similarly across both levels of canopy cover in the transition from seed to established seedling ( 6 weeks; $P=0.423$, see Appendices $\mathrm{B}-\mathrm{D}$ ), they responded differently from seed to $\sim 1$-yr-old seedling $(P$ $=0.006$ ). Mean seed survival (i.e., proportion of seeds that establish as seedlings at 6 weeks) of Microberlinia seedlings $(0.10)$ in the understory was less than half of that in gaps (0.22), and half that of Tetraberlinia in the former $(0.18)$ but similar to that in the latter (0.23). By late November 2008, a total of $321(21 \%)$ and $247(16 \%)$ 
seedlings of Tetraberlinia and Microberlinia, respectively, that started from seed in early September 2007 were alive. The 1-yr seed survival of both species was influenced positively by distance to the nearest Microberlinia adult $(P=0.035)$, and the influence was stronger for 2-yr seed survival ( $P=0.014)$. Nonetheless, 2-yr seed survival of both tree species was similar $(P=0.625)$, and peaked in the gap-exclosure treatment $(P=0.009$; Fig. 6 ). Overall, however, 2 -yr seed survival was $\sim 1.5$ times greater for Tetraberlinia than Microberlinia (mean $\pm \mathrm{SE}$, $0.189 \pm 0.015$ vs. $0.113 \pm 0.012$, respectively; Fig. 6$)$.

Over the 13-month period from October 2007 to November 2008, 1-yr seedling survival in the P-plot was slightly greater for Tetraberlinia than Microberlinia, differing by only 0.07 ( $P<0.001)$. For both species, however, 1-yr seedling survival in the gaps was strongly enhanced by the exclosures compared to the other three treatment combinations ( $P=0.001$; see Fig. 6 insets). When included as a covariate, distance to the nearest Microberlinia adult did not significantly influence 1-yr seedling survival $(P=0.286)$. However, when 2-yr seedling survival was evaluated, the covariate had a slightly significant effect $(P=0.032)$. Otherwise, trends were similar between years except that now the difference between species on average, for all treatments combined, increased to 0.17 . Seedling survival in gaps between November 2008 and November 2009 were much higher for Tetraberlinia at $0.093 \pm 0.05$ and 0.95 \pm 0.04 for controls $(n=29)$ and exclosures $(n=39)$ respectively, than for Microberlinia at $0.56 \pm 0.10(n=$ $40)$ and $0.71 \pm 0.06$ ( $n=96$ quadrats; Fig. 6 insets).

In the T-design for grove-related effects, 1-yr seedling survival from newly established seedlings in October 2007 to November 2008 was significantly higher in Tetraberlinia than Microberlinia $(P<0.0001$; means \pm $\mathrm{SE}, 0.316 \pm 0.023$ vs. $0.243 \pm 0.024$, respectively, $n=$ 104 per species) but almost twice as high in gaps than understory, irrespective of species identity and protection or not from small mammals $(P<0.001$; means \pm SE, $0.37 \pm 0.026$ vs. $0.19 \pm 0.02$, respectively, $n=102$ and 106, Appendix F). The only grove-related effect detected was a marginally significant four-way interaction (grove $\times$ canopy $\times$ predation $\times$ species term, $P=$ 0.033). For 2-yr seedling survival, both species had greater survival in gaps outside vs. inside the grove (means \pm SE were $0.72 \pm 0.04$ vs. $0.50 \pm 0.05, n=53$ and 49, respectively; $P=0.009$ ), whereas the grove effect was reversed for seedlings in the understory (means \pm $\mathrm{SE}$ were $0.34 \pm 0.05$ vs. $0.40 \pm 0.05, n=54$ and 52 , respectively).

Grove-related effects were not discernible for 1-yr seed survival, and the results were similar to those reported above for the P-plot: Microberlinia in the forest understory had the lowest survivorship $(0.11 \pm 0.02)$, half that of Tetraberlinia $(0.23 \pm 0.03)$, while both species had greater, yet similar levels of seed survival in gaps $(0.30-0.32 ; P=0.003$; Appendix F). However, seedlings of both species had $\sim 1.5$ times higher seed survival in the exclosures compared to controls ( $P=$ 0.001 ; means \pm SE, $0.29 \pm 0.02$ vs. $0.19 \pm 0.02$, respectively, $n=120$ per treatment), and this effect persisted when 2-yr seed survival was evaluated $(P<$ 0.001 , means \pm SE, $0.26 \pm 0.02$ vs. $0.15 \pm 0.02$, respectively). However, at this time a grove-related effect, as for 2-yr seedling survival, was discernible $(P=$ 0.021; Appendix F): mean ( \pm SE) 2-yr seed survival, irrespective of species or protection, peaked higher in gaps outside than inside the grove $(0.35 \pm 0.04$ vs. 0.20 \pm 0.03 , respectively) and was greater than in the understory $(0.12 \pm 0.02$ vs. $0.14 \pm 0.02)$.

\section{Seedling growth and herbivory}

For both tree species in the P-plot sample, canopy gaps had by far the strongest, positive impact upon seedling growth and size in all four analyses (all $P$ values $<<0.001$ for four seedling traits investigated, Appendix G). About 13 months after establishment, the gap seedlings had on average three times as many leaves as their understory counterparts (Fig. 7A) because the latter hardly produced any leaves after establishing (Fig. 7B); and they were 50-100\% taller in height (Fig. 7C) due to the much higher relative growth rates compared to the understory (Fig. 7D). Similar trends were already evident 6 months after establishment in April 2008 (not shown). All four size/growth variables were highly positively correlated with one another $(r=0.825$ 0.899, $P<0.001)$.

Nevertheless, there were significant differences in how each species responded to canopy cover in terms of these four size/growth response variables (canopy $\times$ species interaction terms, all four $P$ values $<0.001$, see Appendix $\mathrm{G})$, as well as in their levels of leaf damage $(P=0.045)$. Regarding the former, on average Tetraberlinia seedlings significantly outperformed Microberlinia in the gap environments, but by less than $10 \%$ for leaf number and leaf production over the wet season; but to a greater extent for seedling height and increment, growing at least 25\% faster than Microberlinia did (Fig. 7D), and thus being almost $25 \%$ taller than surviving Microberlinia by November 2008 (Fig. 7C). However, in the understory this trend was reversed for these two traits, in that Microberlinia seedlings had, on average, one more leaf than Tetraberlinia and grew slightly faster in height in the forest understory. Regarding leaf damage (index range 1.0-5.0 corresponding to the five classes of percent area damage), overall, Microberlinia lost a significantly greater percentage of its leaf area than Tetraberlinia did (species term, $P<0.001$, Appendix $\mathrm{G}$, index means $\pm \mathrm{SE}: 2.23 \pm$ 0.074 vs. $1.60 \pm 0.05$, respectively, $n=62$ and $n=67$ ). In the gaps, Microberlinia seedlings had more than twice the percentage of leaf area missing than Tetraberlinia, but this difference was less pronounced in the understory where Tetraberlinia experienced greater damage than in gaps, yet similar for Microberlinia (canopy $\times$ species term, $P=0.045$, Fig. 7E). 

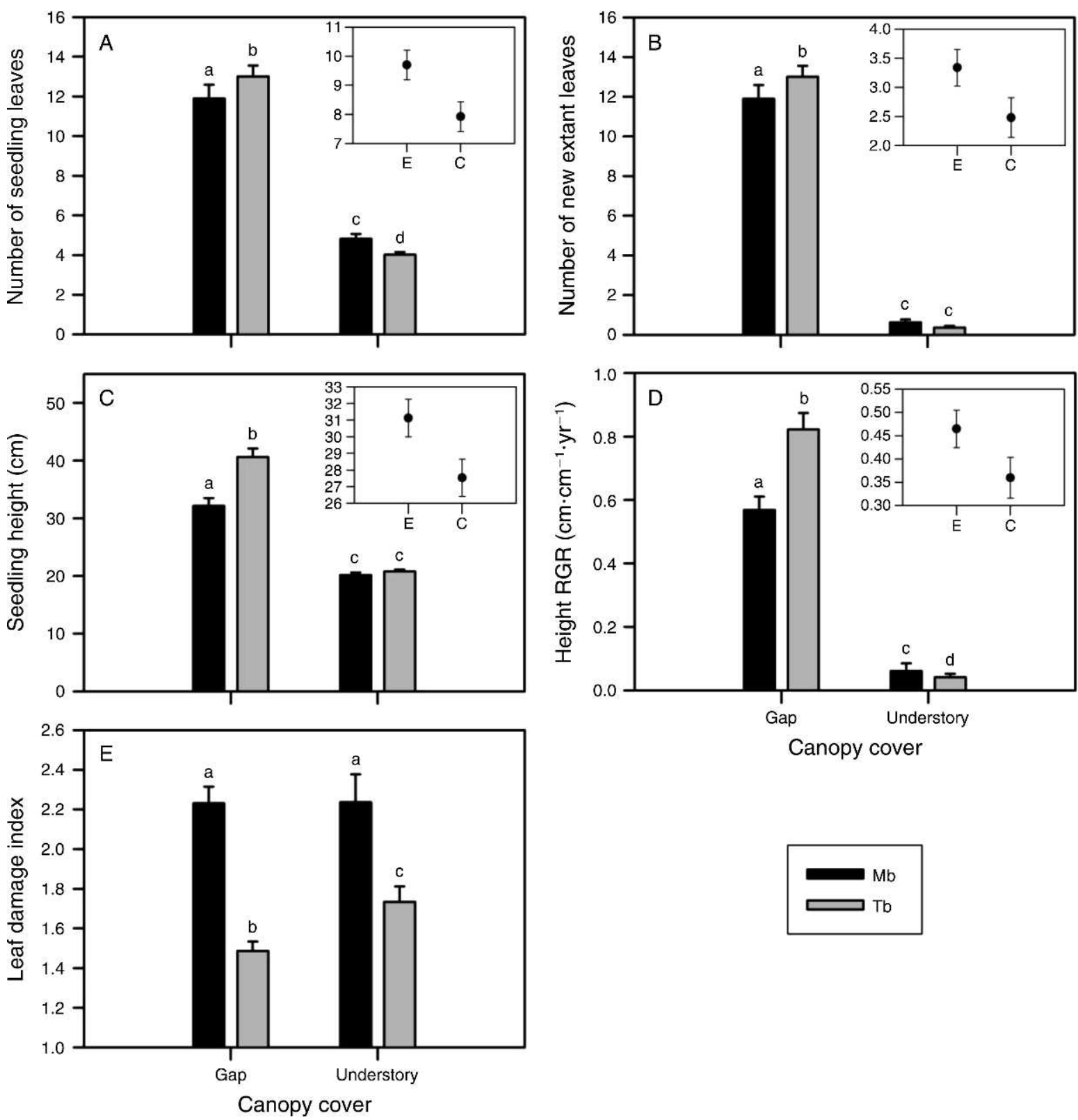

FIG. 7. The effect of canopy cover type on Microberlinia bisulcata $(\mathrm{Mb})$ and Tetraberlinia bifoliolata $(\mathrm{Tb})$ seedling traits in the P-plot in Korup National Park, Cameroon, in terms of (A) number of leaves in November 2008, (B) number of new leaves produced between April and November 2008 still present on the stem, (C) seedling height in November 2008, (D) relative growth rate (RGR) in height between April and November 2008, and (E) static leaf damage scores. Bars are means + SE. Means with different lowercase letters are significantly different at $P<0.05$. The insets show the main effect of predation (control [C] vs. exclosure [E]) for traits. Sample sizes for the bar means, from left to right in each panel: $n=62,67,38$ or 39, and 59 or 60. Sample sizes for means ( \pm SE) of control vs. exclosure in the insets are: (A) $n=131,97$; (B) $n=131,98$; (C) $n=131,97$; and (D) $n=129,89$.

Irrespective of species identity and canopy cover, tree seedlings established in the exclosures had a significantly greater number of leaves present and grew taller than seedlings unprotected from small mammals (predation term, number of leaves, $P<0.001$; new leaves, $P<0.064$; seedling height, $P=0.014 ; \mathrm{RGR}_{\mathrm{ht}}$, $P=0.011$, Fig. 7A-D insets). This main effect was not evident for seedling leaf damage because while slightly more damage was observed in controls vs. exclosures in gaps, the opposite was found in the understory (canopy $\times$ predation term, $P=0.030$, see Appendix G). Seedling leaf damage index (log-transformed) was, however, significantly negatively correlated with $\mathrm{RGR}_{\mathrm{ht}}$ for both Microberlinia and Tetraberlinia in gaps $(r=-0.456, \mathrm{df}=60, P<0.001$; and $r=-0.283$, df $=65, P<0.021)$. 

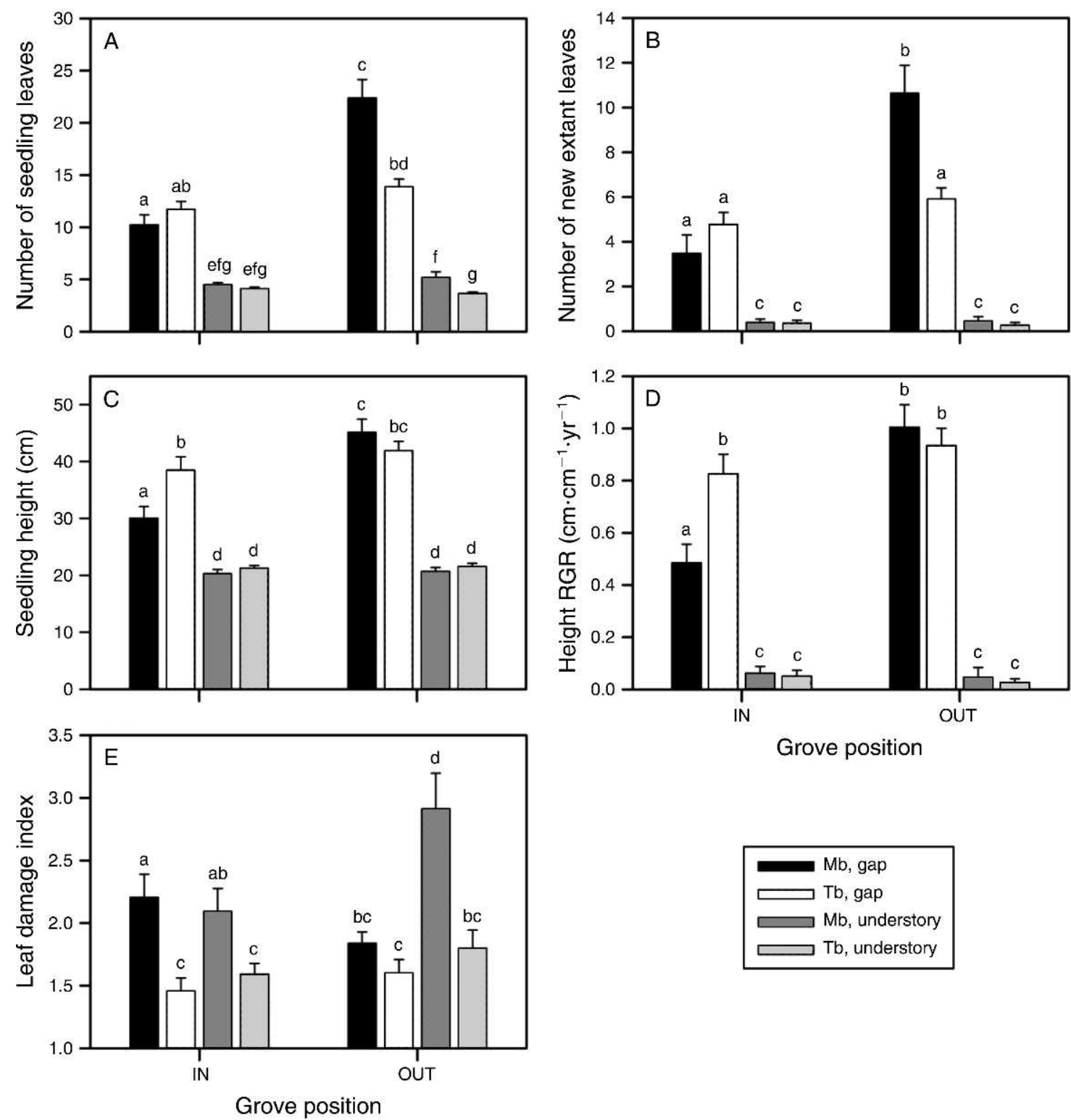

Grove position

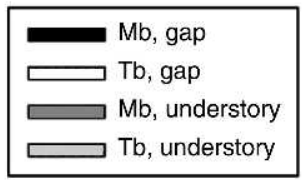

FIG. 8. The influence of the adult Microberlinia bisulcata grove upon a subset of M. bisulcata (Mb) and Tetraberlinia bifoliolata ( $\mathrm{Tb}$ ) seedlings established in canopy gaps and forest understory inside the P-plot (IN) and outside it (OUT) in Korup National Park, Cameroon, in terms of: (A) number of leaves in November 2008, (B) number of new leaves produced between April and November 2008 still present on the stem, (C) seedling height in November 2008, (D) relative growth rate (RGR) in height between April and November 2008, and (E) static leaf damage scores. Bars are means + SE. Means with different lowercase letters are significantly different at $P<0.05$.

Notes: Seedling height (panel D) was included here for consistency and comparative purposes, although the grove $\times$ canopy $\times$ species term was only near significant $(P=0.058)$; all three lower-order two-way interactions among these three terms were highly significant $(P<0.005)$, however. Sample sizes, from left to right in each panel are: IN, $n=20,21,12,22 ;$ OUT, $n=24,26,13,23$ quadrats.

Paralleling the significant grove-related effect for 2-yr seedling survival (Appendix F), strong and complex grove effects were now detected for seedling size, growth and herbivory (see Appendix H). In canopy gaps inside the grove, both Microberlinia and Tetraberlinia seedlings had similar leaf numbers and new extant leaves produced, but outside the grove, Microberlinia increased more than two-fold in these traits, and now significantly outperformed Tetraberlinia by 40-50\% (Fig. 8A and B). Interestingly, Microberlinia also gained an advantage over Tetraberlinia in leaf number in the forest understory outside the grove, although this difference, albeit significant, was small and equivalent to about one leaf on average. Rank reversals in performance were not 

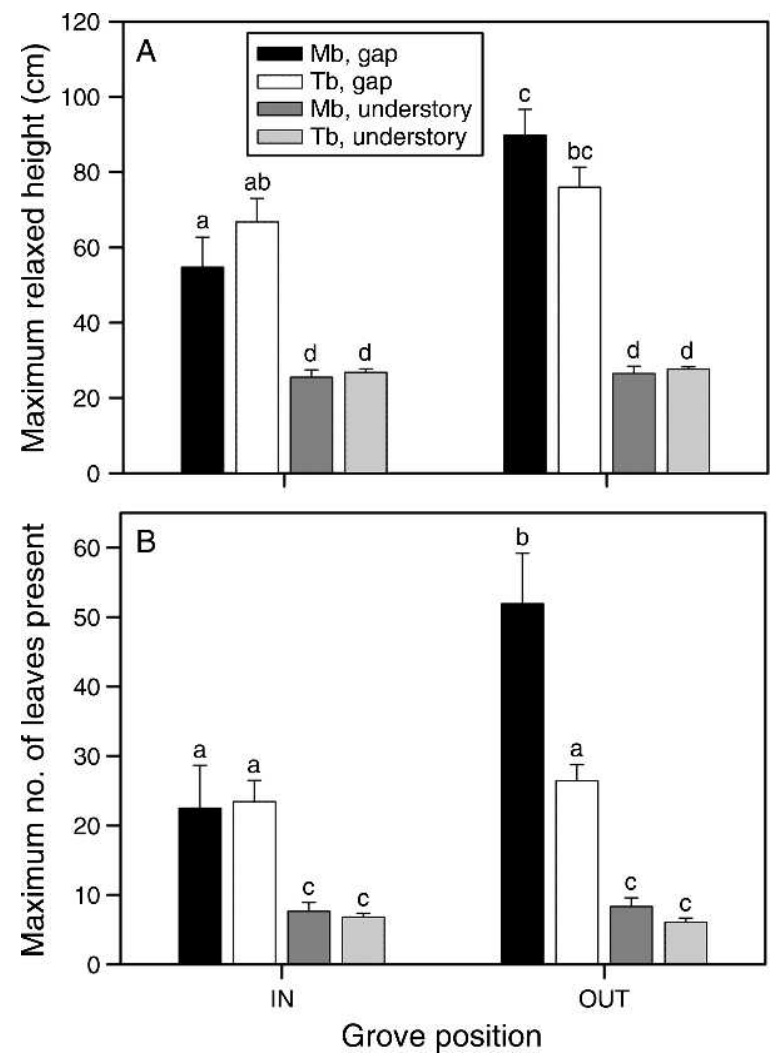

FIG. 9. Final size of "best performing" Microberlinia bisulcata $(\mathrm{Mb})$ and Tetraberlinia bifoliolata $(\mathrm{Tb})$ seedlings in the P-plot in Korup National Park, Cameroon, expressed as (A) maximum relaxed height and (B) maximum number of leaves in late November 2009, in gap and understory locations inside vs. outside the grove of $M$. bisulcata adults. Means (+SE) with different lowercase letters are significantly different at $P<0.05$. Sample sizes are, from left to right in each panel: IN, $n=15,21$, 9, 23; OUT, $n=24,26,9,20$ quadrats (one individual per quadrat).

evident for seedling height and $\mathrm{RGR}_{\mathrm{ht}}$, however. Instead, an "equalizing effect" happened between the two competing species in gaps outside of the grove. Whereas inside the grove Microberlinia height growth in the canopy gaps was only a little more than half that of Tetraberlinia seedlings, outside the grove Microberlinia seedlings doubled their relative growth rates, approaching $\sim 1.00 \mathrm{~cm} \cdot \mathrm{cm}^{-1} \cdot \mathrm{yr}^{-1}$ and were now growing at a rate on par with Tetraberlinia seedlings (Fig. 8D). By contrast, no significant differences in height traits were evident for understory seedlings between species between grove positions (Fig. 8C and D).

In terms of seedling leaf damage, two clear patterns of interest emerged. First, when compared to inside the grove, Microberlinia suffered slightly less leaf area losses when growing in gaps, but twice as much leaf area losses in the forest understory outside the grove (Fig. 8E). The net result was that, whereas in canopy gaps inside the grove Microberlinia had more than twice the leaf damage present as Tetraberlinia did, the two species now shared comparable damage levels outside the grove. In contrast to Microberlinia, Tetraberlinia seedlings showed very little variation in their susceptibility to leaf damage across both levels of canopy cover, or for inside vs. outside the grove (Fig. 8E).

In late November 2009, 173 and 291 seedlings of Microberlinia and Tetraberlinia, respectively, were still alive in the P-plot sample of 48 experimental blocks. From these, we selected the best performer for each quadrat with one or more survivors. The tallest recorded Microberlinia seedling was $143 \mathrm{~cm}$ and the tallest Tetraberlinia was $122 \mathrm{~cm}$. Both of these were in a gap just outside of the northern boundary of the P-plot, and given their far distance from any conspecific adults $(>100 \mathrm{~m})$ were technically outside the Microberlinia grove as defined by the Newbery et al. (2004) cluster analysis. The maximum number of leaves present was 122 and 66 for each species, respectively. Plant size in the understory was generally low for height and leaf number (medians, $26 \mathrm{~cm}$ and six leaves), where after 27 months neither species had any individuals reaching $\geq 50 \mathrm{~cm}$ in height (Appendix B, Fig. 9A). After accounting for the highly positive effect of gaps on plant size, mean maximum height $\sim 25$ months after seedling establishment was significantly greater in Tetraberlinia than Microberlinia (species term, $P<0.0001$, mean \pm SE: $48.3 \pm 2.6$ vs. $42.6 \pm 2.8 \mathrm{~cm}$, respectively), as was leaf number $(P=0.002$, Appendix I, mean \pm SE: $16.4 \pm 1.2$ vs. $14.3 \pm 1.5$, respectively). Interestingly, seedlings of both species in exclosures were significantly taller than in the controls (predation term, $P=0.027$, mean \pm SE: $49.1 \pm 2.6$ vs. $41.6 \pm 2.7 \mathrm{~cm}$, respectively) whereas this yielded no advantage in terms of leaf numbers present $(P$ $=0.35$ ). No significant interactions were detected in the P-plot sample.

The T-design sample, however, gave a slightly different picture when the same analyses were made. As in the P-plot, exclosure seedlings were, on average, $\sim 15 \%$ taller than controls, whether inside or outside the grove of Microberlinia adult trees $(P=0.031)$. But both species had significantly taller individuals in gaps outside than inside the grove (grove $\mathrm{x}$ canopy term, $P=0.017$, Fig. 9A, Appendix J); a trend slightly more pronounced when leaf numbers were considered ( $P=0.004$, Fig. 9B). Also, Microberlinia now performed just as well, if not better in some locations, than Tetraberlinia when growing outside the grove (grove $\times$ species term, $P=$ $0.016)$. Nevertheless, a change in performance seemed to occur more strongly for Microberlinia than Tetraberlinia, going from canopy gaps inside the grove to outside of it, as suggested by a near significant three-way interaction between these three terms (grove $\times$ canopy $\times$ species, $P=0.072$; Fig. 9 , Appendix $\mathrm{J}$ ) and prior growth rate analyses (see Fig. 8).

There were fewer understory quadrats with one or more seedlings in November 2009 for Microberlinia than Tetraberlinia ( 9 and 23 quadrats, respectively). When these understory quadrats were omitted from analyses, 
this species-specific reversal in maximum height attained in gaps was significant (grove $\times$ species, $F_{1,39.9}=7.00, P$ $=0.012$; results not shown, Appendix J). It was even more pronounced for leaf number $\left(F_{1,41.3}=11.2, P=\right.$ 0.002; see Fig. 8B), which amounted to a $125 \%$ increase in leaves when Microberlinia seedlings grew outside the adult Microberlinia grove, despite light availability in gaps being similar inside and outside the grove (see above). Moreover, many of the these Microberlinia gap leaves outside of the grove had a smaller percentage of damage than inside (Fig. 8E), so these differences in plant size using leaf number as a proxy for total intact photosynthetic area are likely conservative. The highest value recorded for Microberlinia was an individual with 145 leaves, whereas inside the grove, the highest was one with 122 leaves. Conversely, the highest value for a Tetraberlinia individual was not necessarily outside the grove (49 leaves), but inside, with 66 leaves.

\section{Spatial patterns in seed fate}

Tests for sampling independence.-When seed fate under the eight treatments was analyzed for the P-plot sample, only three, and possibly a fourth, out of 48 analyses indicated a positive spatial autocorrelation $(P$ $<0.0083$ ) based on Moran's $I$ test. The proportion of Tetraberlinia seeds that established in October 2007 in the controls in gaps were significantly correlated $(P=$ 0.004 ), and so were the proportion of Tetraberlinia seeds eaten by invertebrates in the understory when protected from small mammal predators (i.e., in the exclosures, $P$ $=0.008$ ). The only significant case for Microberlinia was for the proportion of seeds killed by the white fungus pathogen in the understory when exposed to predators $(P=0.003)$. In sum, 37 of 48 tests indicated no evidence for spatial autocorrelation $(P>0.05)$ in seed fate, and of those that did suggest it, five of eight treatments had $P$ values $<0.05$ for when the proportion of seed were infested by both invertebrates and the white fungus.

Apparent mutualism/competition.-To explore these two processes we re-examined seedling establishment in the control quadrats only, which represents what happens under more natural conditions in the forest, for both species in the understory and gaps separately. Control quadrats were grouped into those with both Microberlinia and Tetraberlinia trees present, either Microberlinia or Tetraberlinia present, or neither tree present in a $25-\mathrm{m}$ radius (i.e., four levels). In the understory, for both species, seedling establishment was similar in the presence of the other species and only improved significantly when beyond the crowns $(>25 \mathrm{~m})$ of both species (GLMM, main effect of neighborhood, $F_{3,44}=5.68, P=0.002$; Fig. $10 \mathrm{~B}$ and D). Second, in canopy gaps, Microberlinia seedling establishment appeared to be less than half in the presence of Tetraberlinia than in presence of conspecific stems only, but this was only near significant (GLMM, species nested within neighborhood term, $F_{4,44}=2.57, P=$ 0.051; Fig. 10A and C).
Neighborhood analyses.-Among gap locations, significantly fewer Microberlinia seedlings established in exclosures than in paired controls in areas of increasing conspecific $\mathrm{BA}_{\text {dis } 25}$ (multiple regression, $R^{2}=18.9 \%$; parameter estimate $=-1.454,95 \%$ confidence limits $=$ $\left.-2.637,-0.27, F_{1,45}=6.14, P=0.017\right)$; by contrast, $\mathrm{CO}$ had significant positive effect (parameter estimate $=$ +0.363 , limits $\left.=-0.083,0.643, F_{1,45}=6.81, P=0.012\right)$. A weaker, yet significant influence of this measure for local neighborhood was also detected upon the missing seeds (predation) effect size (parameter estimate $=-0.842$, limits $\left.=-0.029,0.431, F_{1,44}=5.12, P=0.029\right)$ for which $\mathrm{CO}$ was not a significant predictor $(P=0.154)$.

Similarly, for the subset of gap locations within $75 \mathrm{~m}$ of a conspecific adult tree $(n=40$ locations $)$, the protection effect of the exclosures upon Microberlinia seedling establishment increased significantly with distance away from the nearest conspecific adult DIS $_{\text {near75; }}$; parameter estimate $=0.064$, limits $=-0.019,0.109, F_{1,37}$ $=8.38, P=0.006$ ), and also with $\mathrm{CO}$ (parameter estimate $=0.750$, limits $=0.123,1.377, F_{1,37}=5.88, P=$ 0.02 ) (multiple regression, $R^{2}=24.7 \%$ ). The same

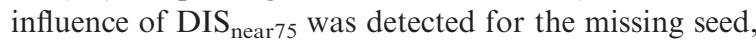
or predation effect size (estimate $=0.040$, limits $=0.013$, $\left.0.066, F_{1,36}=9.26, P=0.004\right)$ but with an insignificant influence of $\mathrm{CO}(P=0.178)$. In contrast to Microberlinia, neither neighborhood metric was a significant predictor for explaining the variation in effect size of Tetraberlinia seeds that established in gaps $(P$ values $0.638,0.669)$; nor was $\mathrm{CO}$ ( $P$ values ranged from 0.785 to 0.068$)$. Although conspecific $\mathrm{BA}_{\mathrm{dis} 25}$ was a negative predictor of effect size of missing seeds, it was not significant $(P=0.130)$. A Spearman-rank correlation against just conspecific $\mathrm{BA}_{\mathrm{dis} 25}$ suggested otherwise, however (adj. correlation $=-0.317, \mathrm{df}=44, t=-2.22, P$ $=0.032$ ). A binomial GLM could not be fitted for DIS $_{\text {near75 }}$ either, but here no significant correlation was detected $(P=0.374, n=17)$. Statistical power was much

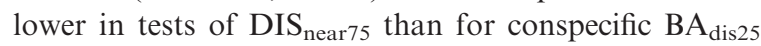
metric as there were fewer gap locations within $75 \mathrm{~m}$ of any Tetraberlinia adult.

In contrast to gaps, in the less disturbed and more shaded understory neither conspecific $\mathrm{BA}_{\mathrm{dis} 25}$ nor DIS $_{\text {near75 had a discernable influence upon effect sizes }}$ of established and missing Microberlinia seeds (all $P$ values: $0.125-0.458)$, nor upon established Tetraberlinia seeds ( $P$ values: $0.614,0.068)$. However, for this latter species, the two GLMs did not fit successfully for effect size of missing seeds (predation effect). Separate Spearman tests were used instead, and revealed a negative correlation with conspecific $\mathrm{BA}_{\mathrm{dis} 25}(-0.261)$ and a positive correlation with $\operatorname{DIS}_{\text {near75 }}(+0.405)$, though not quite significant ( $n=45, P=0.083 ; n=19$, $P=0.086$, respectively).

\section{Tree demography}

Using the data on seed/seedling dynamics in gaps from all 48 experimental blocks in the P-plot, protection 

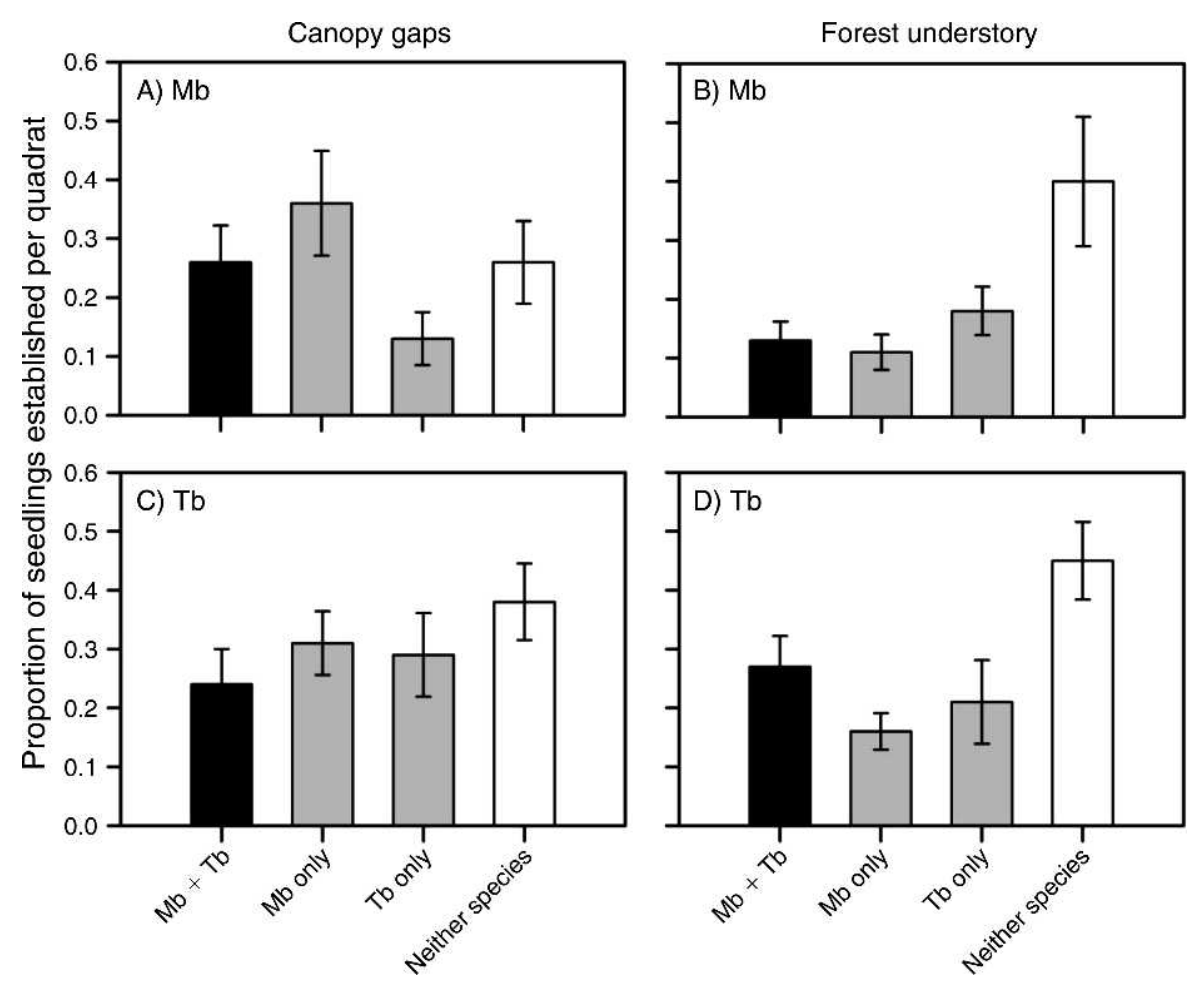

FIG. 10. Proportions of seedlings established from seeds in quadrats exposed to all shared enemy guilds (control treatment) after masting in the P-plot in Korup National Park, Cameroon, for (A, B) Microberlinia bisulcata (Mb) and (C, D) Tetraberlinia bifoliolata $(\mathrm{Tb})$ in canopy gaps and forest understory locations $(n=48$ per canopy cover treatment) that varied in terms of their immediate tree neighborhood within a 25 -m radius of quadrats in four ways: (1) both M. bisulcata and T. bifoliolata stems $\geq 10 \mathrm{~cm}$ dbh (nearly all adult) were present (black bars); (2) only $M$. bisulcata stems present (gray bars); (3) only $T$. bifoliolata stems present (also shown as gray bars); and (4) neither species' stems were nearby (white bars). Sample sizes for gaps and understory for neighborhoods $1-4$ were $n=11,11,13,13$, and $n=12,21,8,7$, respectively. Bars show means \pm SE.

from small mammals increased the population growth rate $(\lambda)$ of Microberlinia from 1.06 to 1.12 . For Tetraberlinia it increased less, from 1.10 to 1.13 .

\section{DisCUSSION}

\section{Seed predators}

We equated seed removal with predation because there is no other obvious explanation for their disappearance. Overall, it was more than two-fold higher in Microberlinia than Tetraberlinia in spite of the former's relatively smaller seed size. Whereas Tetraberlinia may offer a greater energy return per seed-larger-seeded species are expected to be more vulnerable to postdispersal seed removal by foraging small mammals (Smith and Reichman 1984, Vander Wall 1995, Forget et al. 1998, Maron and Crone 2006) - it may also be less attractive compared with Microberlinia if better defended chemically (Janzen 1969; e.g., Henderson 1990). Alternatively, mammals may have avoided Tetraberlinia seeds if these seeds were already infected with the white fungus and/or damaged by invertebrates; not unlike rodents favoring larger-sized seeds within a tree species (Jansen et al. 2004). The second explanation is more plausible because the species difference in seed size is not so great (less than fivefold). Squirrels for example can distinguish between viable and unviable (i.e., infested or aborted) seeds of a temperate pignut hickory tree (Carya glabra), preferring to take the former (Sork and Boucher 1977). Seed mortality of the neotropical palm Socratea exorrhiza due to mammal predation was twice as fast as that caused by insects (Notman and Villegas 2005); however, we could not evaluate removal every 2-3 days in such a large study area. Given the propensity for greater fungal and insect activity during the rainy seasons in tropical rain forests (Givnish 1999), an adaptive ability of seed predators to quickly discriminate among fast-germinating food sources is vital (Jansen et al. 2004).

Understory seed losses in Microberlinia to small mammals was $26.5 \%$ of all unprotected seeds in the 1995 masting at Korup (Green and Newbery 2002), whereas in 2007 (this paper) such losses were higher, at $38.2 \%$ ( $\pm 4.1 \%$ ), suggesting predation pressure from this guild being on average $\sim 32 \%$ and $>25 \%$ across both events. As to which animals in this guild were responsible for predation on Microberlinia and Tetraberlinia seeds, we can only speculate. The most likely candidates are rodents: namely rats (Muridae, up to 25 spp.), including the widespread forest Giant "Pouched" Rat (Cricetomys emini), as well as squirrels (Scuiridae, 
up to 11 species). There are numerous entry holes to burrows in the forest plot, where seeds are likely hoarded too. Other potential mammalian predators known to occur in Korup are real shrews (Sorcidae, up to 12 species); blue (Cephalophus monticola), bay ( $C$. dorsalis), Ogilby's ( $C$. ogilbyi), and yellow-backed $(C$. silvicultor) duikers; the African brush-tailed porcupine (Atherurus africanus); and the forest bushpig (Potamochoerus porcus pictus) (MINFOF 2002).

\section{Seed pathogens}

The white pathogenic fungus, Aphelaria spec. nova (det. P. Roberts, Kew), alone or in conjunction with invertebrate damage, killed relatively many more Tetraberlinia than Microberlinia seeds and germinating seedlings. This points to the possibility of greater host specificity upon Tetraberlinia trees (Janzen 1970, Connell 1971, Gilbert 2005). Moreover, fungal growth was not influenced by canopy cover (Fig. 3A) unlike other seed/seedling pathogens reported for which "damping off" effects are reduced by high light associated with gaps (Augspurger 1983, 1984, Hood et al. 2004). Invertebrates may inadvertently facilitate spread and impact of this fungus on masting seed populations by creating entry points for infection. This is akin to the view that insect herbivores can accelerate pathogen infection of tree seedlings' leaves in the understory of tropical forests (García-Guzmán and Dirzo 2001).

\section{Effects of canopy cover on predation}

For both tree species, small mammals removed more seeds in canopy gaps than in the understory, and conversely more invertebrates killed seeds in the understory than in canopy gaps (Fig. 3A). The general effect size (mean difference in predation levels) between understory and gap habitats was slightly greater for invertebrates than vertebrates, however.

Both woody debris and vine tangles in gaps provide good shelter for small mammals against larger vertebrate (including avian and reptile) predators (IsabiryeBasuta and Kasenene 1989, Schupp and Frost 1989, Beck et al. 2004). By contrast though, while raised light levels and other microclimatic changes may physiologically affect invertebrates in adverse ways, they could also be more susceptible to small mammals as their predators. Seeds in gaps are therefore more likely to be found first by small mammals - rodents in particularand those in the understory later (Schupp 1988, Schupp and Frost 1989, Beck et al. 2004, Norghauer et al. 2006, Carvajal and Adler 2008). Our results suggest that dispersal to canopy gaps can moderate the relative impact of vertebrate vs. invertebrate enemies in the brief seed-to-seedling transition of forest trees to increase establishment there relative to the understory. It is quite plausible that these effects are more pronounced (on average) in larger-sized gaps ( $>10 \%$ canopy openness) or in forests where they are more frequent.
That very few seeds disappeared from exclosures for both species irrespective of canopy cover shows that the treatment was highly effective. But even when protected, Microberlinia was generally more susceptible to invertebrate predation than Tetraberlinia suggesting that if small mammals do not depredate first, the invertebrates will later, so that either or both will limit the recruitment of Microberlinia. Likewise, Tetraberlinia became more susceptible to mortality from the white fungal pathogen when protected from small mammals (Appendix B). Although exclosures also kept out mammalian predators of invertebrates, and thus created potential enemy-free space for invertebrates to more effectively attack Microberlinia seeds, the same cannot be said for the susceptibility of Tetraberlinia to pathogens. Invertebrate predation, however, did not fully offset increased seedling establishment of Microberlinia in exclosures. Not unlike forbs in grasslands (Bricker et al. 2010), we anticipate that, when protected from small mammals, seed limitation intensifies for Microberlinia but not for Tetraberlinia. Compensatory predation among enemy guilds may also occur between masting events in trees: as suggested by the near-identical level of Microberlinia seedling establishment in understory controls between 2007 (here) and 1995 masting events studied (16.9\% [Appendix B] vs. 16.0\% [Green and Newbery 2002]). A similar "enemy-replacement" phenomenon, but greater in severity, was reported from another African rain forest where $84 \%$ of mast seeds of the mono-dominant Gilbertiodendron dewevrei (Caesalpiniaceae) protected against small mammals were killed by specialist curculionid beetles (Hart 1995; also see Hall 2008). The principle that those seeds on the forest floor that mammals do not remove another enemy guild will, was also noted for a temperate conifer tree Pseudotsuga douglasii in Oregon, USA (Harper 1977:147), and for oak seedlings in Britain (Crawley and Long 1995). This phenomenon definitely warrants further investigation as it may be commoner than is often appreciated, especially in Caesalpiniaceae-dominated forests of central Africa.

\section{Predator satiation}

Satiation of pre- and post-dispersal predators can occur at both the tree-population (Silvertown 1980, Boucher 1981) and forest-community level (Harper 1977, Janzen 1974, 1978, Kelly and Sork 2002). Seed satiation of post-dispersal predators (e.g., rodents, wild pigs) has been tested primarily in temperate forests (e.g., Sork et al. 1993, Kitzberger et al. 2007) and in Dipterocarp forests of tropical Southeast Asia (Curran and Webb 2000). At Korup, the possibility for a satiation effect occurs when Microberlinia masts either alone in a given year, or together with Tetraberlinia spp., for which flowering, pod maturation, and seed dispersal follows, on average, 1-3 months later than Microberlinia (Newbery et al. 1998). In the present study, however, experimental seeds were added in a short period of time (early September) during which dispersal of Micro- 
berlinia and Tetraberlinia were overlapping. Microberlinia seed addition therefore simulated an enddispersal phase (late July to mid September) but for Tetraberlinia it was an early-dispersal one (late August to mid October). Thus Microberlinia was exposed to small mammals for longer than Tetraberlinia, which may help explain their differing susceptibilities to them.

We found only slightly higher small mammal predation outside the grove compared with inside it for both species (Fig. 5A), but more seedlings established from seed when protected from mammals outside than inside the grove (Fig. 5B). This suggests that the protection effect against small mammals was enhanced by a lowering of the above-described compensatory effects of invertebrates and white fungus, outside compared to inside the grove. This inference is tentative, however, because in the T-design sampling (15 subplots) a greater proportion of seeds had white fungus ( $40 \%$, Fig. 5A) in the peripheral grove locations than the P-plot as a whole (48 subplots; 10\%, Fig. 5A). That the protection effect weakened in gaps only with increasing conspecific adult basal area for Microberlinia, further indicates that the influence of other enemies was positively densitydependent at this spatial scale, although partially offset by higher light availability. This would be the expected situation if invertebrates were primarily involved (Fig. 5A). In general, invertebrates and fungi can be expected to increase in abundance with an increase in host seed density (Hulme and Benkman 2002).

And while this protection effect in gaps (but not understory) strengthened with distance away from the nearest conspecific live adult tree, so too did the predation effect. Thus Microberlinia, and possibly Tetraberlinia, seeds became more vulnerable to small mammal predation as local seed density declined with proximity to the nearest adult (Ridley 1930, Harper 1977), as predicted if satiation was operating during masting with other enemy guilds playing a correspondingly lesser role. In the 1995 event, small mammal predation of Microberlinia seeds in the understory (gaps were not investigated) was greater $5 \mathrm{~m}$ from the adult tree than $5 \mathrm{~m}$ beyond its crown edge, suggesting, as in 2007 , that post-dispersal satiation was ineffective in the shade.

A key novel finding of our new study is that a satiation effect on small mammals was contingent upon light environment (Schupp 1995, Schupp and Fuentes 1995): it was restricted to locations in or very close to gaps. A conclusive test of post-dispersal satiation, however, would require controlling for the other enemies. Nevertheless, canopy gaps favored tree seedling establishment, and are particularly important for Microberlinia to attain larger sizes and reduce risks of later mortality once light levels attenuate through gap closure. In this context, were it not liable to satiation by masting, post-dispersal predation by small mammals would even further limit Microberlinia seedling abundance in precisely those areas most favorable for its growth and survival. This is akin to what Boucher
(1981) proposed for a grove-forming tropical oak, that it requires many adults packed into groves at high density to satiate its post-dispersal vertebrate enemies, and this might contribute to Microberlinia maintaining its dominance at Korup. The other implication is that there is little advantage in dispersing too far, because rare seed arrivals in canopy gaps are very likely to be found and eaten by rodents. Possibly, this enemy pressure contributed to the evolution of ballistic dispersal in Microberlinia, and its prevalence in the Caesalpiniaceae. As shown for forests elsewhere, this leads to spatial clumping of adults (Seidler and Plotkin 2006), or groves on large scales (Hart 1995, Newbery and Gartlan 1996, Richards 1996).

\section{Apparent mutualism vs. competition}

Apparent mutualisms should favor synchronous seed production among tree species (e.g., Curran and Webb 2000) whereas apparent competition should favor asynchrony (e.g., Schnurr et al. 2002). But our results suggest that distinguishing among such enemy-mediated indirect interactions may be contingent on local disturbance regimes and resulting variation in canopy cover (Chaneton and Bonsall 2000). Our analysis indicated that apparent mutualism is absent (Fig. 10), at least in the seed-to-seedling transition (it may occur in the pre-dispersal stage, however, against primate predators of immature pods). Rather, in the understory, where the vast majority of seeds land, the stems (almost all of adult stature) of both species' function to deter both species seedling recruitment close to them, thereby generating a reciprocal apparent competition and a less host-specific Janzen-Connell effect (Janzen 1970, Carson et al. 2008) that increases their establishment limitation because fewer "safe" sites are available in the forest. A similar effect of apparent competition, but non-reciprocal, was found for seed predation on a common understory tree (Cornus florida) in a temperate forest, which was a function of both its seed density and that of another co-dominant tree (Ilex opaca; Kwit et al. 2004). Further, if Microberlinia seedling recruitment is also poorer in canopy gaps very close to Tetraberlinia stems because of overlapping dispersal (Fig. 10A), which may invite fungal attack and/or host switching by rodents that prefer Microberlinia seeds when available, this further winnows down the number of possible sites suitable for its recruitment into the juvenile size classes. Thus while both predation and clipping directly limits Microberlinia seedling abundance in gaps, so too will it be indirectly limited by proximity to one of its major competitors. In sum, differential susceptibility to different generalist enemy guilds in different microhabitats cancels out any potential benefit of an apparent mutualism via overlapping seed shadows between these species in the post-dispersal seed stage. Our study is among the first to empirically show effects consistent with the reciprocal form of apparent competition (Chaneton and Bonsall 2000), and further highlights 
the importance of considering joint seed deposition patterns of neighboring tree species when evaluating the impact of post-dispersal seed predators, especially in masting tree communities.

\section{Seedling dynamics and herbivory}

Hulme (1998) commented that few studies had quantified predation from multiple guilds of seed predators, particularly in the tropics, and in general the dearth of field experiments that also monitored subsequent seedling dynamics (e.g., Schupp and Fuentes 1995, Curran and Webb 2000, Bricker et al. 2010). At Korup we demonstrated that Microberlinia died faster than Tetraberlinia, and both species survived best when protected from small mammals in gaps (Fig. 6). The main species effect supports prior work that clearly showed a steeper mortality curve for seedlings of Microberlinia compared to $T$. bifoliolata (and $T$. korupensis; Newbery et al. 2006b), which resulted in a $24 \%$ difference in their survivorship after $2 \mathrm{yr}-$ remarkably close to the $23 \%$ we find in the 2007 masting for understory control quadrats. Small mammals continued to have an impact upon newly emerged tree seedlings by clipping their stems $2-5 \mathrm{~cm}$ above ground, and not by eating leaf tissues. This type of clipping below the leaves very often leads to seedling mortality unless large carbohydrate reserves are present (Watt 1919, Harms and Dalling 1997, Armstrong and Westoby 2003), and its prevalence in gaps is expected if these are favored foraging areas of rodents, or home to a higher density of them. Why some gaps had a complete absence of clipping whereas in others nearly all seedlings were eventually clipped remains unexplained, but it may be due to variation in gap sizes and proximity to large fecund trees (Schnurr et al. 2004). In his study of oak regeneration, Watt (1919) long ago reported similar seedling "cut offs." Given that rodents are pervasive in tropical forests (Janzen 1970, 1971, Beck et al. 2004, Jansen et al. 2004, Carvajal and Adler 2008), stemclipping of tree seedlings deserves greater attention and investigation in these ecosystems.

Not too surprisingly, gaps clearly increased seedling performance compared to the more shaded understory where no plants grew $>50 \mathrm{~cm}$ after $2 \mathrm{yr}$ (Appendix B). Perhaps other caesalpiniaceous species require high light levels to reach this threshold quickly. For example, at Korup, two years after the 1995 masting, T. korupensis seedlings did not exceed $30 \mathrm{~cm}$ in height in the shaded forest environment either (Newbery et al. 2006b). Yet the higher growth rates in exclosures reported here is probably, in part, the result of further competition with neighboring vegetation likewise protected from browsing. Even so, Tetraberlinia outperformed Microberlinia in gaps, though the effect sizes were stronger for height than leaf dynamics. These species differences were negligible in the shade where $\mathrm{RGR}_{\mathrm{ht}}$ values were comparable to wild seedlings surveyed in the 1995 masting (range $=0.099-0.151 \mathrm{~cm} \cdot \mathrm{cm}^{-1} \cdot \mathrm{yr}^{-1}$, Newbery et al. 2006b) and where leaf damage resulted from leaf shedding, not herbivory. Thus despite its larger seed size, and ability to persist longer in deep shade (Green and Newbery 2001a), Tetraberlinia still had a faster $\mathrm{RGR}_{\mathrm{ht}}$ than Microberlinia, contrary to a general view of an ecophysiological trade-off between shade tolerance (survival in the shade) and performance (fast growth in the sun) in seedling and saplings of tropical woody species (Gilbert et al. 2006; but see Clark and Clark 1992).

The most plausible explanation, as put forth by Green and Newbery (2001b), is that insect herbivores attacked leaves (and possibly other unstudied plant parts) of vigorously growing Microberlinia more than Tetraberlinia in the P-plot (Fig. 7E), because those of the former are thinner and presumably more palatable to insects. But the improved Microberlinia performance outside compared to within the Microberlinia grove was unexpected (Figs. 8 and 9), as it does not explain why adults are restricted to the grove, and instead suggests a negative conspecific effect of adult trees on seedlings in gaps. This could be driven by unknown herbivores (Janzen 1970, Connell 1971; e.g., Norghauer et al. 2008), and/or a drain of carbon and other nutrients, such as nitrogen and phosphorus, via shared ectomycorrhizal networks (ECM) between parents and progeny (Newbery et al. 1998, Stoll and Newbery 2005). Under present conditions, these two ecological processes together might limit plant recruitment and dominance at the site, but cannot explain the current dearth of juveniles (10-50 $\mathrm{cm} \mathrm{dbh}$ ) beyond the grove perimeter, for which other factors must therefore be compensating the effects we found. Significant grove expansion probably only occurs after large-scale, canopy thinning via successive droughts coming as events every 100-200 yr (Newbery et al. 2004).

\section{Possible implications of predation for population sizes and species co-existence}

In the framework proposed by Chesson (2000), ecological processes could be distinguished in terms of those minimizing differences between species populations' fitness (equalizing forces) and those reducing their growth rate when too abundant (stabilizing forces). In the two-year period since masting - short compared to the lifespan of adult trees- $95 \%$ of Microberlinia and $\sim 81 \%$ of Tetraberlinia seeds placed in the understory were dead. Much, but not all, of this mortality happened rapidly in the brief seed-to-seedling phase (Fig. 6), driven by small mammals in combination with invertebrates and the white fungus, while after establishment other unstudied factors (e.g., too low light, falling debris, trampling by large animals) in addition to fatal stem-clipping from small mammals caused further mortality in the experimental cohorts. Nevertheless, these three enemy guilds, collectively, are a powerful biotic factor limiting seedling abundance at Korup, and thus play an important role in early post- 
dispersal dynamics of this forest. All these deaths must free up space for other tree species; and likely preempt competition in sites most suitable for early growth, such as future gaps. As shown elsewhere, seedling diversity increased in neotropical forest and temperate grassland plots exposed to small mammals compared with plots where they were excluded (Hulme and Benkman 2002, Howe and Brown 2001, Paine and Beck 2007). In their presence Microberlinia establishment was $\sim 20 \%$ lower than Tetraberlinia; an effect greater than the benefit provided to both by canopy gaps on their seedling establishment. We conclude that small mammal predation, and greater leaf herbivory, which is likely density-dependent, together play a pivotal stabilizing role by limiting the seedling abundance of the dominant Microberlinia tree, especially in light-rich canopy gaps. The population modeling exercise lends further support to this inference.

The evidence for apparent competition in the understory, by contrast, may be viewed as a potentially "equalizing" mechanism among co-masting tree species. This generalized form of a Janzen-Connell effect has been poorly studied, in both tropical and temperate forests (Kwit et al. 2004), and highlights the fact that enemies lacking narrow host specificity can forage as facultative specialists during masting events (Janzen 1970). Similarly, small mammal satiation in gaps also represents a potential equalizing force because it improves seedling establishment success for a more light-demanding species (Microberlinia) relative to a more shade-tolerant competitor (Tetraberlinia) less reliant on gaps for persistence (but not growth). Indeed, lower survival in the shade, in addition to lower seedling establishment, further reduces the probability of $\mathrm{Mi}$ croberlinia being at suitable places to experience the later canopy disturbance(s) needed for its growth into larger size classes (Newbery et al. 2010). Clearly Tetraberlinia, being more shade-tolerant in this respect, can build a superior seedling bank, and thus increase its per capita likelihood of encountering a gap formation where it also less susceptible to insect herbivory, in this way augmenting its sapling numbers to very high levels in the forest (Newbery et al. 1998, 2006b). Nevertheless, Microberlinia may offset, in part, this relative disadvantage by producing many more seeds (threefold more) that also disperse more broadly, enabling more of them to land in or near high-light microsites provided by gaps (J. M. Norghauer, unpublished data).

Although we had equal sample sizes for the two microhabitats of interest (to obtain a balanced design needed for statistical analysis) transect sampling in the P-plot in November 2009 (J. M. Norghauer, unpublished data) showed, however, that up to $6.1 \%$ of the forest area is in a gap-like state compared to the surrounding understory matrix where most seeds land. Indeed, seeds of all but true pioneer species in any forest will have the vast majority of its seeds land in the understory (Janzen 1970, Howe and Smallwood 1982, Richards 1996,
Turner 2001). Further, our tentative population modeling exercise points to the possibility that seed and seedling predation in gaps makes them even more limiting for adult recruitment of Microberlinia. Exposure to small mammals decreased $\lambda$ by 0.06 , in line with the average reported in a review of mammalian herbivore impacts on plant population growth (Maron and Crone 2006). That review, however, had only one study of post-dispersal seed predation, for the perennial shrub Lupinus arboreus. Had we also excluded the two other predator guilds, i.e., invertebrates and the white fungal pathogen, this difference may have been greater. The long life spans of trees unfortunately make them difficult study systems for examining herbivore impacts on overall population dynamics. To our knowledge, the present study is one of the first to integrate experimentally derived seed and seedling dynamics data to explore the impact of predation by small mammals on tree demography.

Using the current adult population size, in a given masting year Microberlinia may produce up to 5.8 million seeds whereas Tetraberlinia only 1.9 million. Based on our calculations for seed arrival to gaps and results from this experiment, this would yield $\sim 4300$ Microberlinia seedlings (52 per hectare) and 2800 Tetraberlinia seedlings (34 per hectare) after 2 yr. But Newbery et al. (2010) found only 87 large saplings $(>1$ $\mathrm{m}$ tall) of Microberlinia in 8 ha of forest sampling, or $\sim 11$ individuals per hectare. Thus while the vast majority of deaths have already happened in the seed and early seedling stages, further mortality must accrue for a given cohort of Microberlinia landing in gaps such that another 40 or so individuals per hectare die before reaching $1 \mathrm{~m}$ height. Thus, while seed predation and stem-clipping is a major factor explaining Microberlinia's currently very poor regeneration, this calculation suggests an important role for other ecological factors working to limit Microberlinia abundance in the forest $2 \mathrm{yr}$ after a masting event. These would probably include damage from falling debris, competition, and drought stress, as well as further clipping by small mammals and leaf herbivory by insects, both of which merit further inquiry in this and other forests.

\section{Conclusions}

We conducted a large-scale, multi-factorial experiment to test the relative importance and interaction of several key biotic (seed and seedling enemies) and abiotic factors (canopy gaps) thought to limit the recruitment of tree seedlings in forests (Janzen 1970, 1971, Denslow 1987). In a single ecological setting with sufficient replication at a spatial scale commensurate with adult tree sizes and populations, this approach can be powerful. Here, in a faunally intact African rain forest, mast seeding in Tetraberlinia appears to be rather ineffective at satiating its post-dispersal enemies and in Microberlinia appears effective only against small mammals in gaps. Therefore, on these nutrient-poor 
soils, it is more likely that gregarious masting evolved instead under strong pressure from pre-dispersal predators; namely, large-bodied arboreal primates (Colubus spp.) that feed heavily on pods and seeds (Janzen 1974, McKey et al. 1978). Our results point to pre-dispersal predation, along with complimentary resource matching (Kelly and Sork 2002, Newbery et al. 2006a), as fruitful avenues for future research.

Nevertheless, the strong interactions of animal seed predators with canopy cover may provide important new insights into Microberlinia grove dynamics. This is because large-scale perturbations can reduce canopy cover in two ways: by making gaps more common and/ or larger, or by a thinning of the canopy through leaf shedding under drought stress, either of which should increase ambient light levels in the forest understory. Both scenarios should increase the seedling establishment, growth, and recruitment of light-demanding Microberlinia, in particular, because small mammals in gaps are still liable to satiation after masting events, and drier and hotter understory conditions would have dissuaded invertebrate predators and fungal pathogen activity (Gilbert 2005). A set of successive droughts (as posited by Newbery et al. [2004]) could weaken normally strong establishment limitation (Norghauer and Newbery 2010) and thus promote waves of Microberlinia recruitment by not only increasing general availability of light resources when population density is low, but also by decreasing enemy pressure in the understory (where more leaf litter on the ground might also make it harder for small mammals to find these fast-germinating seeds).

Taken together, our study demonstrated that natural enemies through their interaction with type of forest canopy cover (gaps vs. understory) could play a fundamental role in the early post-dispersal dynamics of the two dominant Korup species. They can do this by modulating the relative effects of survival and growth across varying levels of canopy cover to generate both potentially equalizing forces - in the form of satiation of small mammals in gaps by a more light-demanding species (Microberlinia) and apparent competition between species in the understory - and stabilizing forces - in the form of differential species-specific mortality from enemy guilds and compensatory attacks, and density-dependent insect herbivory in gaps (on Microberlinia). The relative strengths of these forces, however, likely change when considered over longer time scales, and so, too, might their net effect upon forest structure and species composition. In either context, this suite of important enemy-mediated processes can help determine and shape the seedling abundance and distribution of coexisting tree species after masting events in this primary tropical rain forest.

\section{AcKNowledgments}

We are indebted to our Cameroonian field assistants, S. Njibile and C. Okha, for their outstanding help and perseverance working in the forest. This work would not have been possible without the cooperation of G. B. Chuyong (University of Buea) and A. Kembou, Conservator of Korup National Park. We are grateful to the Cameroon Ministry of Forests and the Environment (MINEF: KNP) and the Ministry of Education, Scientific and Technical Research (MINREST) for permission to work in Korup, and to two anonymous reviewers whose comments improved the manuscript.

\section{Literature Cited}

Armstrong, D. P., and M. Westoby. 2003. Seedlings from large seeds tolerate defoliation better: a test using phylogenetically independent contrasts. Ecology 74:1092-1100.

Augspurger, C. K. 1983. Offspring recruitment around tropical trees: changes in cohort distance with time. Oikos 40:189 196.

Augspurger, C. K. 1984. Seedling survival of tropical tree species: interactions of dispersal distance, light-gaps and pathogens. Ecology 65:1705-1712.

Beck, H., M. S. Gaines, J. E. Hines, and J. D. Nichols. 2004. Comparative dynamics of small mammal populations in treefall gaps and surrounding understorey within Amazonian rainforest. Oikos 106:27-38.

Boucher, D. H. 1981. Seed predation by mammals and forest dominance by Quercus oleoides, a tropical lowland oak. Oecologia 49:409-414.

Bricker, M., D. Pearson, and J. Maron. 2010. Small-mammal seed predation limits the recruitment and abundance of two perennial grassland forbs. Ecology 91:85-92.

Carson, W. P., J. T. Anderson, E. G. Leigh, Jr., and S. A. Schnitzer. 2008. Challenges associated with testing and falsifying the Janzen-Connell hypothesis: a review and critique. Pages 210-241 in W. P. Carson, and S. A. Schnitzer, editors. Tropical forest community ecology. Wiley-Blackwell, Oxford, UK.

Carvajal, A., and G. H. Adler. 2008. Seed dispersal and predation by Proechimys semispinosus and Sciurus granatensis in gaps and understorey in central Panama. Journal of Tropical Ecology 24:485-492.

Chambers, J. C., and J. A. MacMahon. 1994. A day in the life of a seed: movements and fates of seeds and their implications for natural and managed systems. Annual Review of Ecology and Systematics 25:263-292.

Chaneton, E. J., and M. B. Bonsall. 2000. Enemy-mediated apparent competition: empirical patterns and the evidence. Oikos 88:380-394.

Chazdon, R. L., and C. B. Field. 1987. Photographic estimation of photosynthetically active radiation: evaluation of a computerized technique. Oecologia 73:525-532.

Chesson, P. 2000. Mechanisms of maintenance of diversity. Annual Review of Ecology and Systematics 31:343-366.

Clark, C. J., J. R. Poulsen, D. J. Levey, and C. W. Osenberg. 2007. Are plant populations seed-limited? A critique and meta-analysis of seed addition experiments. American Naturalist 170:128-142.

Clark, D. A., and D. B. Clark. 1984. Spacing dynamics of a tropical rain forest tree: evaluation of the Janzen-Connell model. American Naturalist 124:769-788.

Clark, D. A., and D. B. Clark. 1992. Life-history diversity of canopy and emergent trees in a neotropical rain forest. Ecological Monographs 62:315-344.

Connell, J. H. 1971. On the role of natural enemies in preventing in some marine animals and in rain forest trees. Pages 298-312 in P. J. den Boer, and G. R. Gradwell, editors. Dynamics of populations. Center for Agricultural Publication and Documentation, Wageninen, The Netherlands.

Crawley, M. J. 1989. Insect herbivores and plant population dynamics. Annual Review of Entomology 34:531-564.

Crawley, M. J., and C. R. Long. 1995. Alternate bearing, predator satiation, and seedling recruitment in Quercus robur L. Journal of Ecology 83:683-696. 
Curran, L. M., and C. O. Webb. 2000. An experimental test of the spatiotemporal scale of seed predation mast-fruiting Dipterocarpaceae. Ecological Monographs 170:129-148.

Dalling, J. W., M. D. Swaine, and N. C. Garwood. 1998. Dispersal patterns and seed bank dynamics of pioneer trees in moist tropical forest. Ecology 79:564-578.

Denslow, J. S. 1987. Tropical rainforest gaps and tree species diversity. Annual Review of Ecology and Systematics $18: 431-451$.

Federer, W. T., and F. King. 2007. Variations on split plot and split block experimental designs. John Wiley and Sons, Hoboken, New Jersey, USA.

Forget, P. M., T. Milleron, and F. Feer. 1998. Patterns in postdispersal seed removal by neotropical rodents and seed fate in relation to seed size. Pages 25-49 in D. M. Newbery, H. T. T. Prins, and N. D. Brown, editors. Dynamics of tropical communities. Blackwell Science, Cambridge, UK.

Frazer, G. W., C. D. Canham, and K. P. Lertzmen. 1999. Gap Light Analyzer (GLA) Version 2.0: imaging software to extract canopy structure and gap light transmission indices from true-colour fisheye photographs, users manual and program documentation. Simon Fraser University, Burnaby, British Columbia, Canada, and the Institute of Ecosystem Studies, Millbrook, New York, USA.

Galwey, N. W. 2006. Introduction to mixed modeling: beyond regression and analysis of variance. John Wiley and Sons, West Sussex, UK.

García-Guzmán, G., and R. Dirzo. 2001. Patterns of leafpathogen infection in the understory of a Mexican rain forest: incidence, spatiotemporal variation, and mechanisms of infection. American Journal of Botany 88:634-645.

Gartlan, J. S. 1992. Cameroon. Pages 110-118 in J. A. Sayer, C. S. Harcourt, and N. M. Collins, editors. The conservation atlas of tropical forests: Africa. Macmillan Publishers, London, UK.

Garwood, N. C. 1996. Functional morphology of tropical tree seedlings. Pages 59-130 in M. D. Swaine, editor. Ecology of tropical rain forest seedlings. UNESCO/Parthenon, Paris, France.

Gilbert, B., S. J. Wright, H. Muller-Landau, K. Kitajima, and A. Hernandéz. 2006. Life-history tradeoffs in tropical trees and lianas. Ecology 87:1281-1288.

Gilbert, G. S. 2005. Dimensions of plant disease in tropical forests. Pages 141-164 in D. F. R. P. Burslem, S. E. Pinard, and S. E. Hartley, editors. Biotic interactions in the tropics: their role in the maintenance of species diversity. Cambridge University Press, Cambridge, UK.

Givnish, T. J. 1999. On the causes of gradients in tropical tree diversity. Journal of Ecology 87:193-210.

Green, J. J., and D. M. Newbery. 2001a. Light and seed size affect establishment of grove-forming ectomycorrhizal rain forest tree species. New Phytologist 151:271-289.

Green, J. J., and D. M. Newbery. 2001b. Shade and leaf loss affect establishment of grove-forming ectomycorrhizal rain forest tree species. New Phytologist 151:291-309.

Green, J. J., and D. M. Newbery. 2002. Reproductive investment and seedling survival of the mast fruiting tree, Microberlinia bisulcata A. Chev. Plant Ecology 162:169-183.

Hall, J. S. 2008. Seed and seedling survival of African mahogany (Entandophragma spp.) in the Central African Republic: implications for forest management. Forest Ecology and Management 255:292-299.

Hammond, D. S., and V. K. Brown. 1998. Disturbance, phenology, and life-history characteristics: factors influencing distant/density-dependent attack on tropical seeds and seedlings. Pages 51-79 in D. M. Newbery, H. T. T. Prins, and N. D. Brown, editors. Dynamics of tropical communities. Blackwell Science, Cambridge, UK.

Harms, K. E., and J. W. Dalling. 1997. Damage and herbivory tolerance through resprouting as an advantage of large seed size in tropical trees and lianas. Journal of Tropical Ecology $13: 617-621$.
Harms, K. E., S. J. Wright, O. Calderon, A. Hernandez, and A. E. Herre. 2000. Pervasive density-dependent recruitment enhances seedling diversity in a tropical forest. Nature 404:493-495.

Harper, J. L. 1977. Population biology of plants. Academic Press, London, UK.

Hart, T. B. 1995. Seed, seedling, and sub-canopy survival in monodominant and mixed forests of the Ituri Forest, Africa. Journal of Tropical Ecology 11:443-459.

Hartshorn, G. S. 1978. Tree falls and tropical forest dynamics. Pages 617-638 in P. B. Tomlinson, and M. H. Zimmerman, editors. Tropical trees as living systems. Cambridge University Press, Cambridge, UK.

Henderson, C. B. 1990. The influence of seed apparency, nutrient content and chemical defenses on dietary preference of Dipodymus ordii. Oecologia 82:333-341.

Henkel, T., W. J. R. Mayor, and L. P. Woolley. 2005. Mastfruiting and seedling survival of the ectomycorrhizal, monodominant Dicymbe corymbosa (Caesalpiniaceae) in Guyana. New Phytologist 167:543-556.

Holt, R. D., and J. H. Lawton. 1994. The ecological consequences of shared natural enemies. Annual Review of Ecology and Systematics 25:495-520.

Hood, L. A., M. D. Swaine, and P. A. Mason. 2004. The influence of spatial patterns of damping-off disease and arbuscular mycorrhizal colonization on tree seedling establishment in Ghanaian tropical forest soil. Journal of Ecology 92:816-823.

Howe, H. F., and J. S. Brown. 2001. The ghost of granivory past. Ecology Letters 4:371-378.

Howe, H. F., E. W. Schupp, and L. C. Westley. 1985. Early consequences of seed dispersal for a neotropical tree (Virola surinamensis). Ecology 66:781-791.

Howe, H. F., and J. Smallwood. 1982. Ecology of seed dispersal. Annual Review of Ecology and Systematics 13:201-228.

Hulme, P. E. 1998. Post-dispersal seed predation: consequences for plant demography. Perspectives in Plant Ecology, Systematics, and Evolution 1:32-46.

Hulme, P. E., and C. W. Benkman. 2002. Granivory. Pages 132-154 in C. A. Herrera, and O. Pellmyr, editors. Plantanimal interactions: an evolutionary approach. Blackwell Publishing, Oxford, UK.

Hulme, P. E., and J. Kollmann. 2005. Seed predator guilds, spatial variation in post-dispersal seed predation and potential effects on plant demography: a temperate perspective. Pages 9-30 in P. M. Forget, J. E. Lambert, P. E. Hulme, and S. B. Vander Wall, editors. Seed fate: predation, dispersal and seedling establishment. CABI Publishing, Oxfordshire, UK.

Isabirye-Basuta, G., and J. M. Kasenene. 1989. Small rodent populations in selectively felled and mature tracts of Kibale Forest, Uganda. Biotropica 19:260-266.

Jansen, P. A., F. Bongers, and L. Hemerik. 2004. Seed mass and mast seeding enhance dispersal by a Neotropical scatterhoarding rodent. Ecological Monographs 74:569-589.

Janzen, D. H. 1969. Seed-eaters versus seed size, number, toxicity and dispersal. Evolution 23:1-27.

Janzen, D. H. 1970. Herbivores and the number of tree species in tropical forests. American Naturalist 104:501-528.

Janzen, D. H. 1971. Seed predation by animals. Annual Review of Ecology and Systematics 33:427-447.

Janzen, D. H. 1974. Tropical blackwaters, animals, and mast fruiting by the Dipterocarpaceae. Biotropica 6:69-103.

Janzen, D. H. 1978. Seedling patterns of tropical trees. Pages 83-128 in P. B. Tomlinson, and M. H. Zimmerman, editors. Tropical trees as living systems. Cambridge University Press, Cambridge, UK.

Kelly, D., and V. L. Sork. 2002. Mast seeding in perennial plants: how, when, where? Annual Review of Ecology and Systematics 2:465-492. 
Kitzberger, T., E. J. Chaneton, and F. Caccia. 2007. Indirect effects of prey swamping: differential seed predation during a bamboo masting event. Ecology 88:2541-2554.

Kobe, R., and C. F. Vriesendorp. 2009. Size of sampling unit strongly influences detection of seedling limitation in a wet tropical forest. Ecology Letters 12:220-228.

Kwit, C., D. J. Levey, and C. H. Greenberg. 2004. Contagious seed dispersal beneath heterospecific fruiting trees and its consequences. Oikos 107:303-308.

Lieberman, D. 1996. Demography of tropical tree seedlings: a review. Pages 131-138 in M. D. Swaine, editor. Ecology of tropical rain forest seedlings. UNESCO/Parthenon, Paris, France.

Losos, E. 1995. Habitat-specificity of two palm species: experimental transplantation in Amazonian successional forest. Ecology 76:2595-2606.

Maron, J. L., and E. Crone. 2006. Herbivory: effects on plant abundance, distribution and population growth. Proceedings of the Royal Society B 273:2575-2584.

McKey, D., P. G. Waterman, C. N. Mbi, J. S. Gartlan, and T. Struhsaker. 1978. Phenolic content of vegetation in two African rain forests: ecological implications. Science 202:6164.

Mellanby, K. 1968. The effects of some mammals and birds on regeneration of oak. Journal of Applied Ecology 5:359-366.

MINFOF. 2002. A management plan for Korup National Park and its peripheral zone: 2003-2007. Ministry of the Environment and Forestry, Republic of Cameroon.

Moles, A. T., D. I. Warton, and M. Westoby. 2003. Do smallseeded species have higher survival through seed predation than large-seeded species? Ecology 84:3148-3161.

Newbery, D. M., I. J. Alexander, and J. A. Rother. 1997. Phosphorus dynamics in a lowland rain forest: the influence of ectomycorrhizal trees. Ecological Monographs 67:367409.

Newbery, D. M., I. J. Alexander, D. W. Thomas, and J. S. Gartlan. 1988. Ectomycorrhizal rain forest legumes and soil phosphorus in Korup National Park, Cameroon. New Phytologist 109:433-450.

Newbery, D. M., G. B. Chuyong, and L. Zimmermann. $2006 a$. Mast fruiting of large ectomycorrhizal African rain forest trees: importance of dry season intensity, and the resource limitation hypothesis. New Phytologist 170:561-579.

Newbery, D. M., G. B. Chuyong, L. Zimmerman, and C. Praz. 2006b. Seedling survival and growth of three ectomycorrhizal caesalpiniaceous tree species in a Central African rain forest. Journal of Tropical Ecology 22:499-511.

Newbery, D. M., and J. S. Gartlan. 1996. A structural analysis of rain forest at Korup and Doual-Edea, Cameroon. Proceedings of the Royal Society of Edinburgh 104B:177-224.

Newbery, D. M., C. P. Praz, X. M. van der Burgt, J. M. Norghauer, and G. B. Chuyong. 2010. Recruitment dynamics of the grove-dominant tree Microberlinia bisulcata in African rain forest: extending the light response versus adult longevity concept. Plant Ecology 206:151-172.

Newbery, D. M., S. Schwan, G. B. Chuyong, and X. M. van der Burgt. 2009. Buttress form of the central African rain forest tree Microberlinia bisulcata, and its possible role in nutrient acquisition. Trees - Structure and Function 23:219-234.

Newbery, D. M., N. C. Songwe, and G. B. Chuyong. 1998. Phenology and dynamics of an African rainforest at Korup, Cameroon. Pages 267-308 in D. M. Newbery, H. H. T. Prins, and N. D. Brown. Dynamics of tropical communities. Blackwell Science, Oxford, UK.

Newbery, D. M., X. M. van der Burgt, and M. A. Moravie. 2004. Structure and inferred dynamics of a large grove of Microberlinia bisulcata trees in central African rain forest: the possible role of periods of multiple disturbance events. Journal of Tropical Ecology 20:131-143.

Norghauer, J. M., J. R. Malcolm, and B. L. Zimmerman. 2008. Canopy cover mediates interactions between a specialist caterpillar and seedlings of a neotropical tree. Journal of Ecology 96:103-113.

Norghauer, J. M., J. R. Malcolm, B. L. Zimmerman, and J. M. Felfili. 2006. An experimental test of distance- and densitydependent recruitment of mahogany (Swietenia macrophylla) in southeastern Amazonia. Oecologia 148:437-446.

Norghauer, J. M., and D. M. Newbery. 2010. Recruitment limitation after mast-seeding in two African rain forest trees. Ecology 91:2303-2012.

Notman, E. V., and A. C. Villegas. 2005. Patterns of seed predation by vertebrate versus invertebrate seed predators among different plant species, seasons, and spatial distributions. Pages 55-75 in P. M. Forget, J. E. Lambert, P. E. Hulme, and S. B. Vander Wall, editors. Seed fate: predation, dispersal and seedling establishment. CABI Publishing, Oxfordshire, UK.

Osunkjoya, O. O., J. E. Hash, M. S. Hopkins, and A. W. Graham. 1992. Factors affecting survival of tree seedlings in North Queensland rainforests. Oecologia 91:569-578.

Packer, A., and K. Clay. 2000. Soil pathogens and spatial patterns of seedling mortality of a temperate tree. Nature 404:278-281.

Paine, C. E., and H. Beck. 2007. Seed predation by neotropical small mammals increases diversity of seedling recruitment. Ecology 88:3076-3087.

Poulsen, J. R., C. W. Osenberg, C. J. Clark, D. J. Levey, and B. M. Bolker. 2007. Plants as reef fish: fitting the functional form of seedling recruitment. American Naturalist 170:167183.

Richards, P. W. 1996. The tropical rain forest: an ecological study. Second edition. Cambridge University Press, Cambridge, UK.

Ridley, H. N. 1930. The dispersal of plants throughout the world. L. Reeve and Company, Kent, UK.

Schnurr, J. L., C. D. Canham, R. S. Ostfeld, and R. S. Inouye. 2004. Neighborhood analyses of small mammal dynamics: impacts on seed predation and seedling establishment. Ecology 85:741-555.

Schnurr, J. L., R. S. Ostfeld, and C. D. Canham. 2002. Direct and indirect effects of masting on rodent populations and tree seed survival. Oikos 96:402-410.

Schupp, E. W. 1988. Seed and early seedling predation in the forest understory and in treefall gaps. Oikos 51:71-78.

Schupp, E. W. 1992. The Janzen-Connell model for tropical tree diversity: population implications and the importance of spatial scale. American Naturalist 140:526-530.

Schupp, E. W. 1995. Seed seedling conflicts, habitat choice, and patterns of plant recruitment. American Journal of Botany 82:399-409.

Schupp, E. W., and E. J. Frost. 1989. Differential predation of Welfia georgii seeds in treefall gaps and the forest understory. Biotropica 21:200-203.

Schupp, E. W., and M. Fuentes. 1995. Spatial patterns of seed dispersal and the unification of plant population ecology. Ecoscience 2:267-275.

Seidler, T. G., and J. B. Plotkin. 2006. Seed dispersal and spatial pattern in tropical trees. PLoS Biology 4(11):e344.

Shugart, H. H. 1984. A theory of forest dynamics. Blackburn Press, Caldwell, USA.

Silman, M., J. W. Terborgh, and R. A. Kiltie. 2003. Population regulation of a dominant rain forest tree by a major seed predator. Ecology 84:431-438.

Silvertown, J. S. 1980. The evolutionary ecology of mast seeding in trees. Botanical Journal of the Linnean Society 14:235-250.

Smith, C. C., and O. J. Reichman. 1984. Evolution of food caching by birds and mammals. Annual Review of Ecology and Systematics 15:329-351.

Sork, V. L. 1987. Effects of predation and light on seedling establishment of Gustavia superba. Ecology 68:1341-1350. 
Sork, V. L., and D. H. Boucher. 1977. Dispersal of sweet pignut hickory in a year of low fruit production, and the influence of predation by a curculionid beetle. Oecologia 28:289-299.

Sork, V. L., J. Bramble, and O. Sexton. 1993. The ecology of mast-fruiting in three species of North American oaks. Ecology 74:528-541.

Stoll, P., and D. M. Newbery. 2005. Evidence of species-specific neighborhood effects in the Dipterocarpaceae of a Bornean rain forest. Ecology 86:3048-3062.

Tomita, M., Y. Hirabuki, and K. Seiwa. 2002. Post-dispersal changes in the spatial distribution of Fagus crenata seeds. Ecology 83:1560-1565.
Turner, I. M. 2001. The ecology of trees in the tropical rain forest. Cambridge University Press, Cambridge, UK.

Vander Wall, S. B. 1995. The effect of seed value on the caching behavior of yellow pine chipmunks. Oikos 74:533-537.

Watt, A. S. 1947. Pattern and process in the plant community. Journal of Ecology 35:1-22.

Watt, J. S. 1919. On the causes of failure of natural regeneration in British oakwoods. Journal of Ecology 7:173-203.

Whitmore, T. C. 1998. An introduction to tropical rain forests. Second edition. Oxford University Press, Oxford, UK.

\section{APPENDIX A}

Map of the 82.5-ha P-plot in Korup National Park (Cameroon) showing the location of experimental blocks and the overall nested design (Ecological Archives M081-015-A1).

\section{APPENDIX B}

A summary table of the individual fates of experimental tree seeds (Ecological Archives M081-015-A2).

\section{APPENDIX C}

ANOVA statistical tables for the five seed fates investigated in the P-plot sample (Ecological Archives M081-015-A3).

\section{APPENDIX D}

ANOVA statistical tables for the five seed fates investigated inside compared to outside the grove of Microberlinia bisulcata trees (Ecological Archives M081-015-A4).

\section{APPENDIX E}

GLMM and ANOVA statistical tables for 1- and 2-yr seedling survival and seed survival, respectively (Ecological Archives M081-015-A5).

\section{APPENDIX F}

GLMM and ANOVA statistical tables for 1- and 2-yr seedling survival and seed survival, respectively, inside compared to outside the grove of Microberlinia bisulcata trees (Ecological Archives M081-015-A6).

\section{APPENDIX G}

LMM statistical tables for seedling size, growth, and leaf damage in the P-plot sample (Ecological Archives M081-015-A7).

\section{APPENDIX H}

LMM statistical tables for seedling size, growth, and leaf damage inside compared to outside the grove of Microberlinia bisulcata trees (Ecological Archives M081-015-A8).

\section{APPENDIX I}

LMM statistical tables for maximum height and leaf numbers of seedlings in the P-plot sample (Ecological Archives M081-015-A9).

\section{APPENDIX J}

LMM statistical tables for maximum height and leaf numbers of seedlings inside compared to outside the grove of Microberlinia bisulcata trees (Ecological Archives M081-015-A10).

\section{APPENDIX K}

Stage-based life tables constructed for Microberlinia bisulcata and Tetraberlinia bifoliolata tree populations (Ecological Archives M081-015-A11).

\section{APPENDIX L}

Population matrices constructed for Microberlinia bisulcata and Tetraberlinia bifoliolata trees at Korup (Ecological Archives M081-015-A12). 